\title{
LA ARQUITECTURA DEL PLENO BARROCO EN GRANADA: EL HOSPITAL DEL CORPUS CHRISTI
}

\author{
POR \\ Juan Manuel Barrios Rozúa \\ E. T. S. de Arquitectura de Granada
}

\begin{abstract}
El hospital del Corpus Christi de Granada fue víctima de los prejuicios contra el barroco de influyentes historiadores. Sin embargo, el edificio constituye un interesante ejemplo de arquitectura hospitalaria con un templo francamente original. Gracias al análisis exhaustivo de su completo archivo, puede detectarse la labor de una treintena de artífices, entre ellos Alonso Cano y su discípulo Juan Luis de Ortega, cuyas obras arquitectónicas son valoradas aquí.
\end{abstract}

Palabras clave: Arquitectura; Barroco; Hermandades; Juan Luis de Ortega.

\section{HIGH BAROQUE ARCHITECTURE IN GRANADA: THE CORPUS CHRISTI HOSPITAL}

The Corpus Christi hospital of Granada was a victim of prejudices against the baroque on the part of influential historians. Nevertheless, the building is an interesting example of hospital architecture with a frankly original temple. Thanks to the exhaustive analysis of the institution's very complete archive, it can be determined that some thirty artists worked there, including Alonso Cano and his disciple Juan Luis de Ortega, whose architectural works are evaluated here.

Key words: Architecture; Baroque; Brotherhoods; Juan Luis de Ortega.

\section{Un singular edificio menospreciado por la historiografia}

La pequeña iglesia del hospital del Corpus Christi, conocida popularmente como Hospitalicos y desde 1898 templo de los agustinos recoletos, no ha gozado de fortuna crítica. Manuel GómezMoreno González, que nunca llegó a superar los prejuicios de su tiempo hacia el barroco, diría que la iglesia está "recargadísima de mal ornato y con mezquina traza"1, aunque no escapó a su

${ }^{1}$ Gómez-Moreno González, M., Guía de Granada (2 vols.), Granada, Imprenta de Indalecio Ventura, 1892 (ed. facs. con introducción de Gómez-Moreno Calera, J. M., Universidad, 1994), p. 316. 


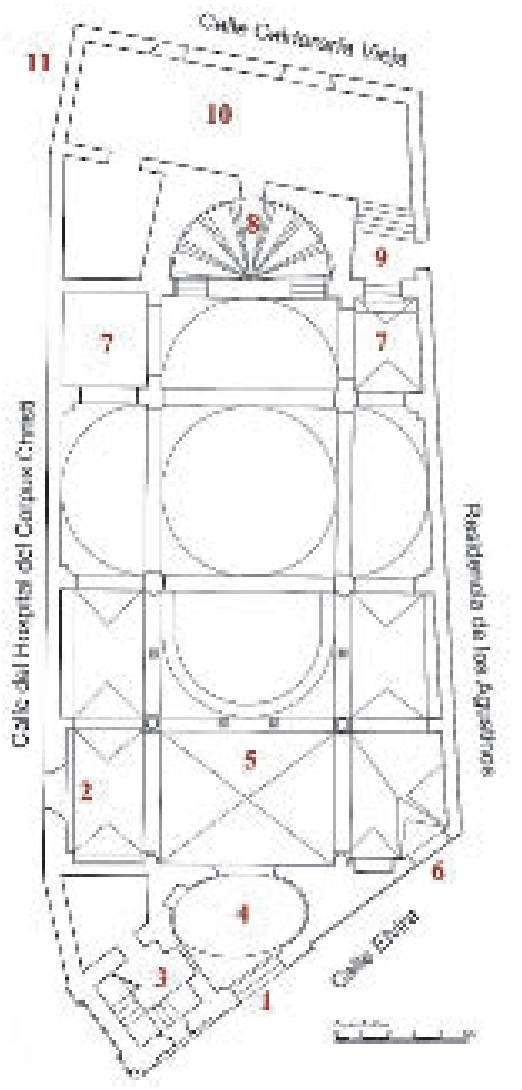

\author{
1. Puerte prineipul \\ 2. Puerta interal \\ 3. Torre \\ 4. Niritex \\ 5. Sotacino \\ 6. Ventana del sntacoro \\ 7, Capillas nueras, antes \\ salas tecesotias \\ 8. Capilla mayor \\ 9. Aceeso a la resideadin \\ de aguastines recoletes \\ 10. Saeristía \\ 11. Puerta del Hespital, \\ hoy tapiada
}

aguda mirada la originalidad de una planta que "no se parece a ninguna otra" de las que hay en la ciudad ${ }^{2}$. Su contemporáneo Francisco de Paula Valladar sentenció que el templo es de "muy mal gusto"3; pero, qué otra cosa podía opinar alguien que calificaba el barroco como "estilo decadente que inició en Roma el arquitecto Bernini y desarrolló Borromini”, o que tacha la herencia arquitectónica del siglo XVIII como "de escaso valer"4. Antonio Gallego Burín, autor de un ensayo pionero que reivindicó el barroco granadino, tampoco fue compasivo con el edificio, al que calificó de templo "de tres naves de pobre traza abundantemente ornamentadas"5. Esto se decía de la iglesia en las tres principales guías que tuvo la ciudad hasta mediados del siglo XX, lo que explica que Hospitalicos no haya atraído nunca a demasiados interesados en el arte. René Taylor fue el que prestó más atención al edificio, en especial a sus ornamentaciones, pero no estableció su proceso constructivo ${ }^{6}$.

2 “Arquitectura en Granada", trabajo inédito escrito hacia 1877, en GóMEZ-MorEno GonZÁLEz, M., Obra dispersa e inédita, introducido por Moya Morales, J., Granada, Fundación Rodríguez Acosta, 2004, p. 560.

3 Valladar y Serrano, F. P., Guía de Granada. Historia, descripciones, artes, costumbres, investigaciones arqueológicas, Granada, Paulino Ventura Traveset, 1906, p. 201.

${ }^{4}$ Valladar y Serrano, F. P., Historia del Arte. Arquitectura, Barcelona, Librería de Antonio J. Bastinos, 1894 , pp. 440 y 443.

${ }^{5}$ Gallego Burín, A., Granada. Guía artística e histórica de la ciudad, Madrid, Fundación Rodríguez-Acosta, 1961 (primera edición publicada por entregas entre 1936 y 1944), p. 454.

6 Véase TAYLOR, R., "El arquitecto José Granados de la Barrera", Cuadernos de Arte, XII (1975), p. 11. 


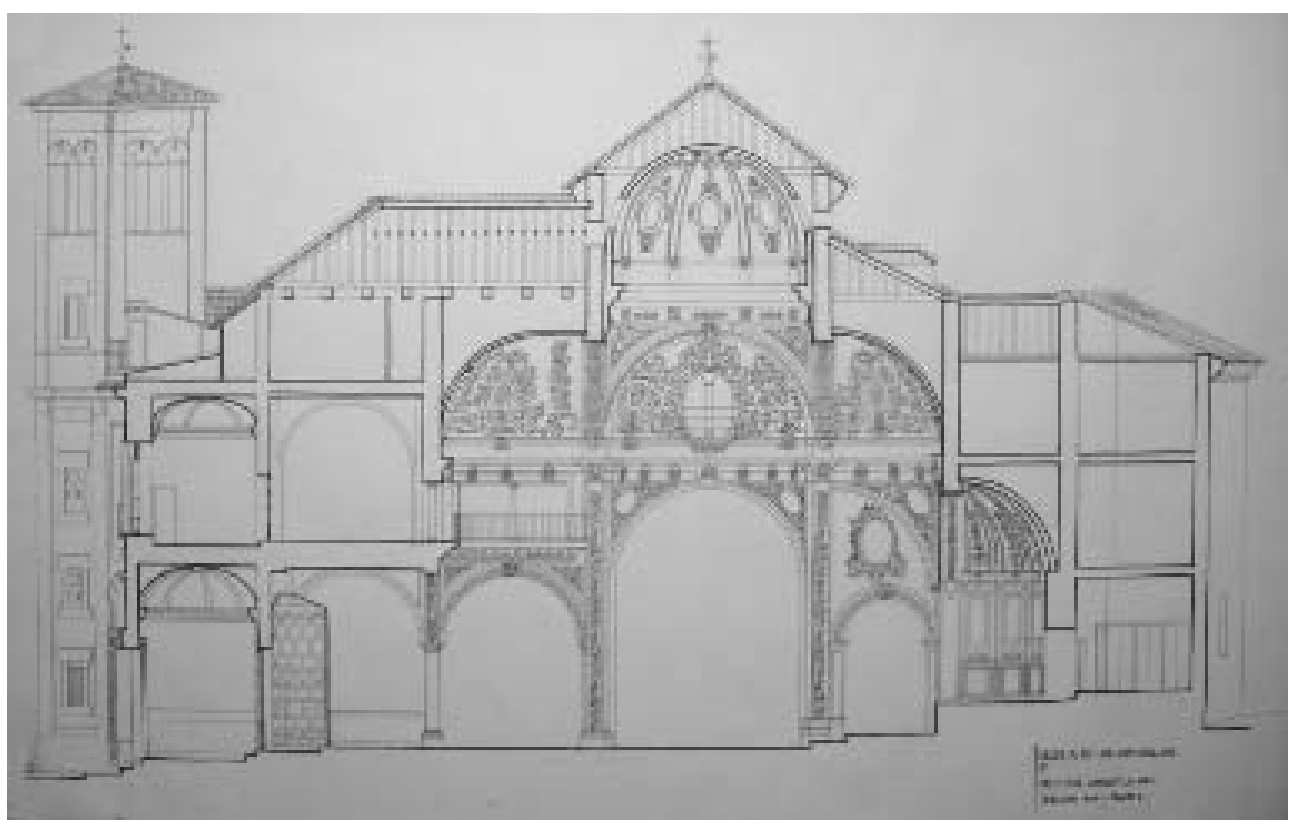

Fig. 2. Sección longitudinal de la iglesia (dibujo de Carlos Sánchez Gómez).

Sin embargo, el hospital del Corpus Christi no merece estos juicios severos porque reúne indudables valores históricos y artísticos. Es el único ejemplo de arquitectura hospitalaria de una hermandad que ha conservado Granada y, además, presenta un buen estado de conservación. Su portada, aunque toscamente labrada, fue trazada por Alonso Cano, y el templo, si bien de reducido tamaño, es de gran original en el panorama andaluz y cuenta con interesantes decoraciones de yeso $^{7}$.

\section{La traza de Bernabé Martín y la junta de maestros}

La Hermandad del Corpus Christi, Ánimas y Misericordia nació en Santa Fe al final de la Guerra de Granada, aunque sus reglas no fueron aprobadas hasta 1514. Tres años después adquirió una casa-mesón junto a la calle Elvira ${ }^{8}$, en la cual estableció un hospital, una capilla y las dependencias necesarias para las reuniones y actividad de una hermandad. El edificio albergó con el tiempo un estimable número de pinturas y esculturas, algunas donadas por los propios autores,

\footnotetext{
${ }^{7}$ Quiero agradecer a los agustinos recoletos de Granada y a Francisco Javier Martínez Medina, profesor de la Facultad de Teología, las facilidades que me han dado para realizar esta investigación. Hago extensivos los agradecimientos al arquitecto Carlos Sánchez, que me ha permitido reproducir y consultar dibujos inéditos y de excepcional interés que hizo de la iglesia en los años setenta del pasado siglo.

${ }^{8}$ Sobre la fundación y primeras etapas de la hermandad véase De LA ChiCA Benavides, A., Gazetilla curiosa o Semanero Granadino, noticioso, y útil para el bien común, 7 mayo 1765, MárTIR Alario, M. J., Historia de la cofradía y hospital del corpus Christi de Misericordia y Animas Benditas del Purgatorio de la ciudad de Granada, durante el siglo XVI, Granada, 1985 (memoria de licenciatura inédita), pp. 32-35 y LóPEZ-GuADALuPE MuÑoz, M. L., La labor benéfico-social de las cofradías en la Granada Moderna, Granada, Universidad, 1994, pp. 74-75.
} 


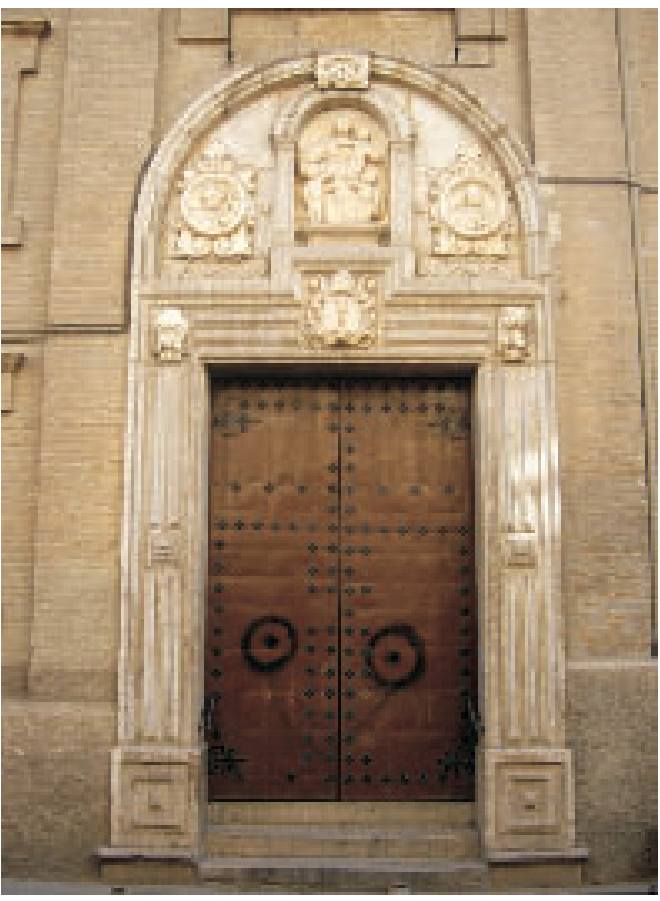

Fig. 3. Portada del templo trazada por Alonso Cano.

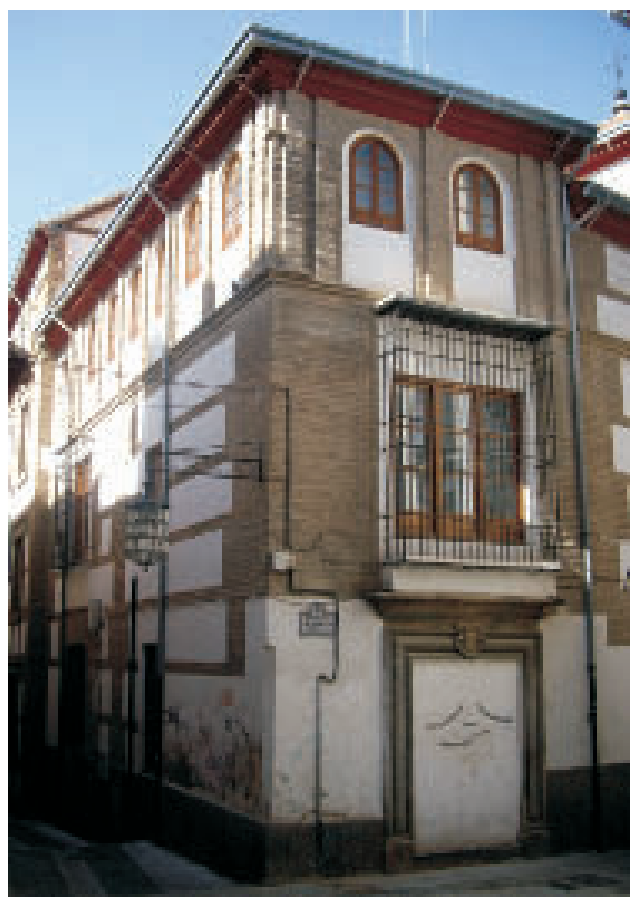

Fig. 4. Fachada y puerta cegada del hospital.

puesto que la hermandad aglutinó a numerosos artistas y artesanos, siendo uno de sus primeros miembros el arquitecto y escultor Diego de Siloé, quien donó a la hermandad una viña de 22 marjales 9 . Entre 1625 y 1634 el edificio que ocupaba la hermandad fue objeto de diversas remodelaciones, aunque mantuvo su estructura en torno a un patio mientras que el oratorio, renovado en estilo protobarroco y dotado de un pequeño campanario, siguió siendo de reducidas dimensiones ${ }^{10}$.

En 1654 fue nombrado mayordomo de la hermandad el famoso escultor Pedro de Mena y Medrano (1628-1688), el cual tuvo claro desde el primer día que era preciso construir un templo más amplio y suntuoso ${ }^{11}$. El artista se había formado con su padre Alonso de Mena, destacado escultor que falleció en 1646 y fue enterrado en la iglesia de Hospitalicos ${ }^{12}$. Pedro de Mena heredó el taller de su padre y cuando Alonso Cano llegó a la ciudad en 1652 lo puso a su servicio, siendo el primero en recibir una intensa influencia del polifacético creador, con quien estableció una relación de auténtica amistad. Pedro de Mena era un hombre muy religioso, de ahí su impli-

9 Archivo Histórico del Corpus Christi, en adelante AHCC, L-45. Aparece registrado entre los hermanos como "el maestro Siloée", como puede verse en la trascripción del registro de los primeros miembros de la hermandad que hace Mártir Alario, op. cit., p. 235.

${ }^{10}$ Como veremos, el edificio fue derribado por completo en el ultimo tercio del siglo, por lo que no merece la pena entrar aquí en detalles sobre su proceso constructivo, el cual puede rastrearse en AHCC, L-31.

11 Es muy amplia la bibliografía existente sobre Pedro de Mena, para estas líneas he tomado como referencia: GilA Medina, L., Pedro de Mena escultor, 1628-1688, Madrid, Arco Libros, 2007, pp. 41-67.

${ }^{12}$ Murió el 4 de septiembre de 1646 y su voluntad de ser enterrado en Hospitalicos aparece en el Archivo Diocesano. Gallego Burín, A., Estudios de escultura española, introducido por SÁnchez-Mesa Martín, D., Granada, Universidad de Granada, 2006, p. 156. 
cación en la hermandad, de la que fue mayordomo y luego hermano mayor, hasta que en 1658 marchó a Málaga, ciudad en la que se establecería.

La iniciativa de este artista debió de ser crucial para que la hermandad se decidiera a construir un nuevo templo. Al finalizar el año 1654 Pedro de Mena rindió cuentas de su gestión y explicó a sus compañeros los gastos de los trabajos preparatorios. El primer paso había sido la compra de una casa y de un pedazo de caballeriza que lindaban con el hospital ${ }^{13}$, para lo cual se recurrió como tasadores al maestro de cantería Juan de Rueda y al maestro de albañilería Marcos Rojo ${ }^{14}$. La casa y la caballeriza se comenzaron a derribar el 24 de abril de 1654, colaborando por turnos algunos hermanos en la demolición y evacuación de los escombros. Tras terminar la limpieza del solar, el 5 de agosto se puso la primera piedra de la que en adelante se iba a llamar "capilla nueva" o del Santo Cristo, dado que el antiguo templo y el hospital seguirían funcionando hasta que terminaran las obras.

Todo parece indicar que la traza del templo se encargó mientras se realizaban las labores de desescombro y que el día de la colocación de la primera piedra el diseño aún no estaba ultimado. Cuando se tuvo el proyecto, Pedro de Mena convocó una junta de maestros:

"Mas en 12 de dicho [noviembre] se iço una Junta de maestros para ber una traça que dio Bernabé Martín para dicha obra i ber un modelo de dicha traça. Y se llamaron los siguientes: Luis de Segura i el Racionero Alonso Cano i el capitan Roque Calero i el maestro Juan de Rueda i los demas que se pudieron agregar para Conferir el acierto y se le dio por buena, se le dio de su trabajo ocho Reales de a ocho y se le dieron por tasacion de dichos maestros i con acuerdo del Hermano maior i mayordomo" $"$.

Los maestros convocados participaron desinteresadamente -sólo se les invitó a unos dulces- movidos por su amistad hacia Pedro de Mena o como gesto caritativo hacia una hermandad de labor generosa y reconocida en la ciudad. Bernabé Martín, el autor de la traza, era un maestro de carpintería y ebanista que fallecería en 1661, o sea, mucho antes de que concluyeran las obras del templo ${ }^{16}$. Su nombre no vuelve a aparecer en las cuentas de gastos, señal de que delegó el seguimiento de las obras en otros. Lo más probable es que su proyecto fuera el que se siguió en líneas generales hasta la conclusión de las obras, dado que nunca es cuestionado ni se hace referencia al encargo de una nueva traza. La aparición de este arquitecto desconocido no tiene nada de peculiar, pues, como señalara René Taylor: "Uno de los mayores encantos de la arquitectura barroca española es la cantidad de maestros menores que realizan obras de gran trascendencia, dentro de un marco esencialmente local" 17 .

${ }^{13}$ La casa era propiedad de Cristóbal Maldonado y el pedazo de caballeriza de Lucas de Meneses. Al parecer Cristóbal Maldonado también vendió a la comunidad un pequeño pedazo de terreno que se destinará a la sacristía; quizás porque el precio era muy ventajoso, se le regala una escultura del Niño Jesús de tres cuartas de alto. AHCC, L-31.

14 AHCC, L-31. Marcos Rojo falleció hacia 1678; su actividad en otras obras está documentada en GILA MEDINA, L., Maestros de cantería y albañilería en la Granada moderna, según los escribanos de la ciudad, Granada, Colegio Notarial, 2000, pp. 523-524.

15 AHCC, L-31.

${ }^{16}$ El 8 de agosto de 1661 su viuda Agustina de Escalona pedía que se hiciera un inventario de los bienes de su marido, vecino de la parroquia de San Gil. En el inventario figuraban algunos cuadros de tema religioso. Noticia del Archivo de Protocolos Notariales de Granada recogida por Gila Medina, L., Maestros de carpintería en la Granada Moderna según los escribanos de la ciudad, Granada, Colegio Notarial de Granada, 2008, p. 151.

${ }_{17}$ Prólogo de René Taylor a Rivas Carmona, J., Arquitectura y policromía: los mármoles del Barroco andaluz, Córdoba, Diputación Provincial, 1990, p. 14.

Arch. esp. arte, LXXXIV, 333, ENERO-MARZO 2011, 1-24, ISSN: 0004-0428 


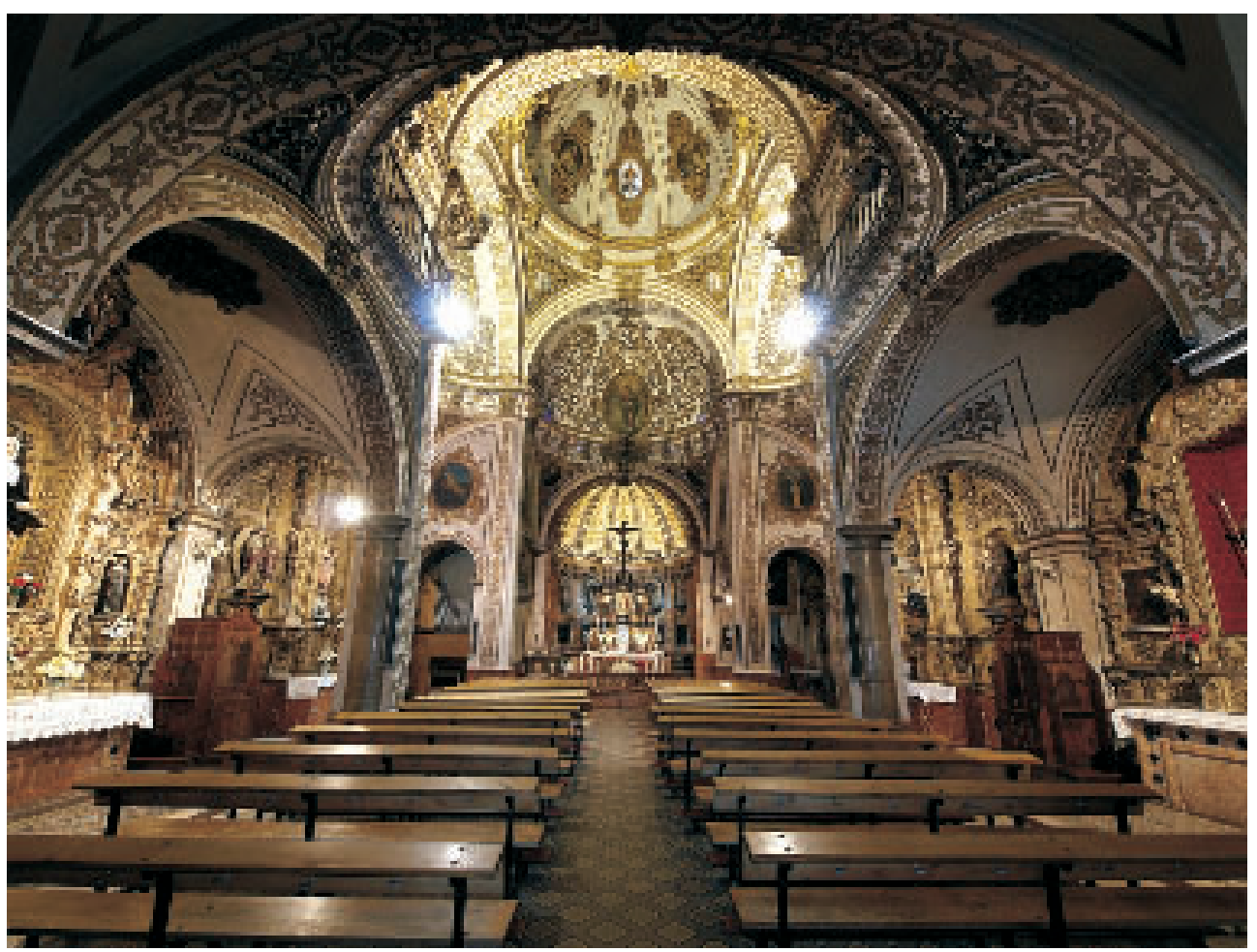

Fig. 5. Vista general de la iglesia hacia la cabecera (imagen tomada con gran angular). Fotografía Juan Miguel García.

Los otros maestros consultados, ¿se limitaron a dar el visto bueno al proyecto en una reunión distendida? ¿Hicieron sugerencias? La lacónica documentación no dice nada más y, puesto que sólo recoge los gastos de la obra, ignoramos si presentaron algunas aportaciones. No sabemos nada del capitán Roque Calero, que posiblemente era lo que hoy llamaríamos un ingeniero militar, mientras que de Luis de Segura sólo sabemos que era maestro de carpintería. En cualquier caso no constan como miembros de la hermandad en sus libros de registro.

Juan de Rueda es un activo maestro de obras perteneciente a una familia de gran tradición en los trabajos de la ciudad ${ }^{18}$. Ya hemos podido ver su participación en los trabajos de desescombro y luego continuará trabajando en las tareas de cimentación y levantamiento de los primeros muros y pilares. Juan de Rueda fue el autor de la traza de la basílica de las Angustias (1663), edificio del que luego hablaré.

Caso aparte es el del racionero Alonso Cano. Sabemos por el historiador Antonio Gallego Burín que Pedro de Mena declaró haber recibido una traza del polifacético artista para la portada de la iglesia ${ }^{19}$, la cual es sin duda la que sirvió de modelo a la que hoy vemos. Mi impresión es,

18 Aunque no se indica el apellido, debe tratarse del maestro de albañilería Juan de Rueda Moreno, el cual ocupó los puestos de maestro mayor de las obras de la ciudad y de la Alhambra en las fechas que nos ocupan. GómEZ-MORENo GonZÁlez, Guía..., op. cit., pp. 557-559; Gila Medina, Maestros de cantería..., op. cit., pp. 258-261.

19 Aunque Gallego Burín no cita la fuente que ha consultado, es absolutamente fiable. Dice que "se acordó renovar el edificio, encargándose a Alonso Cano, en 1654, el trazado de portada nueva, cuyo diseño llegó a hacer, informando sobre él Pedro de Mena" (Gallego Burín, Granada..., op. cit. p. 453). Otros historiadores han querido situarla en el 
además, que Alonso Cano no se limitó a dar esa traza para la portada y que siguió implicándose en las obras, siempre de manera desinteresada. La generosidad de la que hizo gala en la ciudad es proverbial y ésta impide precisamente que pueda figurar en los libros de cuentas de la hermandad. La colaboración de Cano se detecta indudablemente en el campo de la ornamentación. Pensemos que un año antes se había iniciado la construcción de la enigmática iglesia del convento del Ángel Custodio y que el maestro de obras que supervisaba los trabajos era su discípulo Juan Luis de Ortega. Como más adelante veremos, Ortega ingresó en la hermandad en 1658 y dio un fuerte impulso a los trabajos de la iglesia de Hospitalicos. Es más que probable que consultara al racionero, sobre cuya discutida trayectoria como arquitecto haré unas consideraciones antes de seguir con el relato de las obras.

\section{Alonso Cano y su labor como arquitecto en Granada}

Alonso Cano era hijo del ensamblador Miguel Cano, quien precisamente ingresó en la hermandad del hospital del Corpus Christi en $1600^{20}$, un año antes del nacimiento de su hijo. Alonso sólo pasaría los primeros años de su vida en Granada, pues Miguel y toda su familia partieron para Sevilla en busca de mejores encargos. En ella se formó Alonso, casó dos veces y echaron raíces la mayoría de sus hermanos y hermanas ${ }^{21}$. Cuando ya era un artista consagrado en la ciudad del Guadalquivir marchó a Madrid para trabajar al servicio del conde-duque de Olivares y, pese a la caída en desgracia de éste, nunca le faltaron trabajos en la corte. Extraña por ello que decidiera "retirarse" a su ciudad natal en la última etapa de su vida.

La Granada con la que se reencontró en 1652 era una ciudad de segundo orden en comparación con Madrid o Sevilla, tanto por su posición periférica como por la expulsión de los moriscos. Es cierto que por su número de pobladores seguía siendo una urbe nada desdeñable, que su feraz Vega y la industria de la seda constituían una sólida base económica, y que la Chancillería era un polo de atracción que rompía un posible ensimismamiento provinciano, pero, qué duda cabe, para uno de los mejores artistas del país, Madrid, Sevilla o una ciudad emergente como Valencia eran opciones con muchas más posibilidades de promoción profesional. Es cierto que en Granada no le iba a faltar trabajo y que la propia decoración de la capilla mayor de la Catedral era un atractivo encargo, pero Cano era consciente de que iba a cobrar poco para su reconocida categoría artística. Para colmo, su deseo de ordenarse sacerdote tropezó con los obstáculos del cabildo catedralicio, donde encontró una fuerte hostilidad, me temo que no tanto por los incumplimientos de los que se le acusa en la vida religiosa y en los trabajos, como por la altivez con la que trató a los canónigos 22 .

Alonso Cano siempre había sentido un especial interés por la arquitectura, y desde muy joven trabajó en el campo del retablo, oficio que aprendió de su padre Miguel Cano. Por ello, además

entorno de Melchor de Aguirre [CAmacho Martínez, R. y Galera Andreu, P., "La arquitectura de la Alta Andalucía", en El arte del Barroco. Urbanismo y arquitectura, (Historia del Arte en Andalucía, vol. VI), Sevilla, Gever, 1990, p. 138], pero en mi opinión está mucho más próxima a ciertos diseños para retablos de Cano que a cualquiera de las portadas que hizo Melchor de Aguirre, que son bastante más densas, como ocurre, por ejemplo, con la portada lateral de la iglesia de San Felipe Neri.

20 Mártir Alario, op. cit., p. 264.

${ }^{21}$ Para Alonso Cano sigue siendo de referencia la biografía trazada en Wethey, H. E., Alonso Cano. Pintor, escultor y arquitecto, Madrid, Alianza, 1983, pp. 23-35.

${ }^{22} \mathrm{Su}$ difícil relación con el cabildo eclesiástico puede verse en las propias fuentes documentales transcritas en Orozco Pardo, J. L., Alonso Cano. Documentación de las Actas Capitulares de la Catedral de Granada, Granada, Diputación Provincial, 1986. 


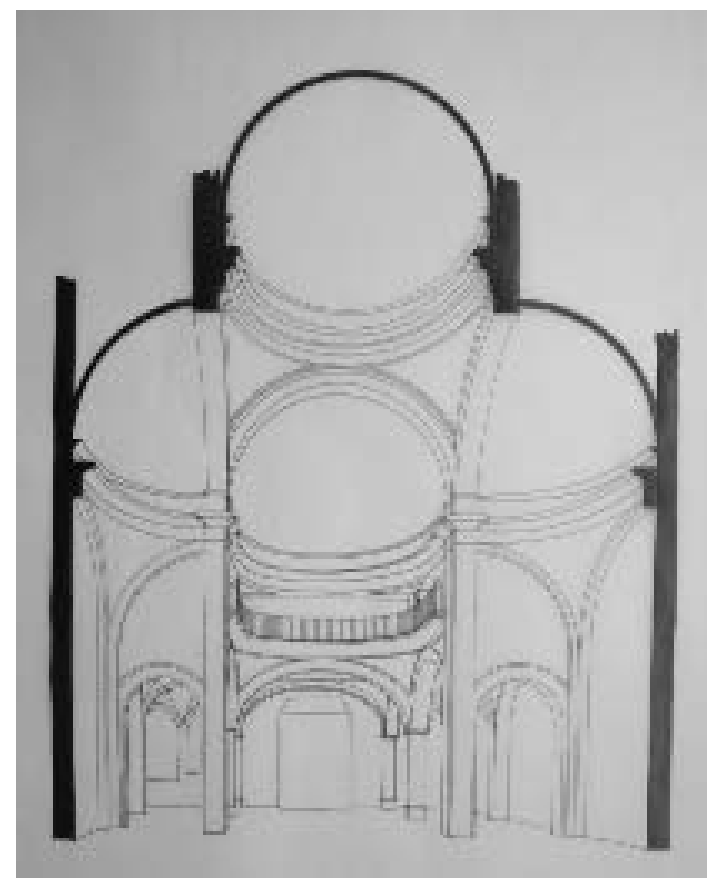

Fig. 6. Sección transversal de la iglesia vista hacia los pies (dibujo de Carlos Sánchez Gómez). de pintor y escultor siempre se consideró arquitecto y aspiró en distintas ocasiones a ejercer como tal, aunque no siempre tuvo suerte. Granada le va a ofrecer las oportunidades deseadas, pues la ciudad cuenta con una Catedral inacabada y numerosos conventos que desean sumarse al esplendor barroco. El estilo dominante cuando él llega oscilaba entre el tardío renacimiento y el protobarroco, careciendo de figuras de relieve a excepción del jesuita Francisco Díaz del Ribero. Esto va a permitir a Alonso Cano marcar su futura trayectoria con las novedosas concepciones de la decoración y el juego de volúmenes que ya apuntara en Madrid.

Aunque en Granada es poco lo que se le atribuye en el campo de la arquitectura, a saber, la desaparecida iglesia del Ángel Custodio, la fachada de la Catedral y la portada de Hospitalicos, más algún retablo perdido, la implicación de Cano en las obras de la ciudad debió ir mucho más allá. Su participación desinteresada en la junta de maestros que veíamos antes es una prueba de cómo se le pide consejo, algo que debió ocurrir en diversas ocasiones, ya por parte de los clérigos promotores,

ya por parte de los artífices. Desgraciadamente, durante las desamortizaciones desaparecieron no sólo muchos cenobios barrocos, sino también los archivos conventuales, lo cual hace difícil rastrear la actividad o influencia de Cano en un periodo en el que se están labrando o embelleciendo los desaparecidos conventos de Agustinos Descalzos, Mercedarios Descalzos o el ya citado Ángel Custodio, amén de casas señoriales como la de los Siete Moros y ermitas como la del Santo Sepulcro de los Rebites ${ }^{23}$.

A la hora de valorar a Alonso Cano como arquitecto, cuyo ingenio diseñando retablos reconocían todos sus contemporáneos ${ }^{24}$, se ha insistido con frecuencia en los problemas estructurales que presentó la iglesia del Ángel Custodio, tomando este suceso como la evidencia de que era en esencia un pintor y escultor sin formación técnica para la arquitectura. También se saca a colación el informe negativo para la maestría mayor de obras de la Catedral de Toledo que hizo el artífice Gómez de Mora, el cual defendía su único ámbito de actividad de lo que consideraba

23 Todos estos edificios desaparecidos los analizo en mis libros Reforma urbana y destrucción del patrimonio histórico en Granada. Ciudad y desamortización, Granada, Universidad de Granada y Junta de Andalucía, 1998, pp. 312-320, 403-410 y 453-457, y Guía de la Granada desaparecida, Granada, Comares, 1999, pp. 161-163.

${ }^{24}$ Sobre los retablos de Alonso Cano hace una buena síntesis Rodríguez G. DE Ceballos, que además hace esta consideración que, en mi opinión, no puede hacerse extensiva a su etapa granadina: "Alonso Cano fue un renovador ante todo en el ornato de la arquitectura y del retablo, conduciendo a este último, particularmente, de un clasicismo descarnado a un clasicismo ornamentado. Pienso que no se le puede continuar considerando como un arquitecto constructor ni a él le hubiese agradado que le encasillasen en esta categoría”, RodRíGUEZ G. DE CEBALlos, A., "Alonso Cano y el retablo", en Figuras e imágenes del Barroco: estudios sobre el barroco español y sobre la obra de Alonso Cano, Madrid, Visor, 1999, p. 252. 


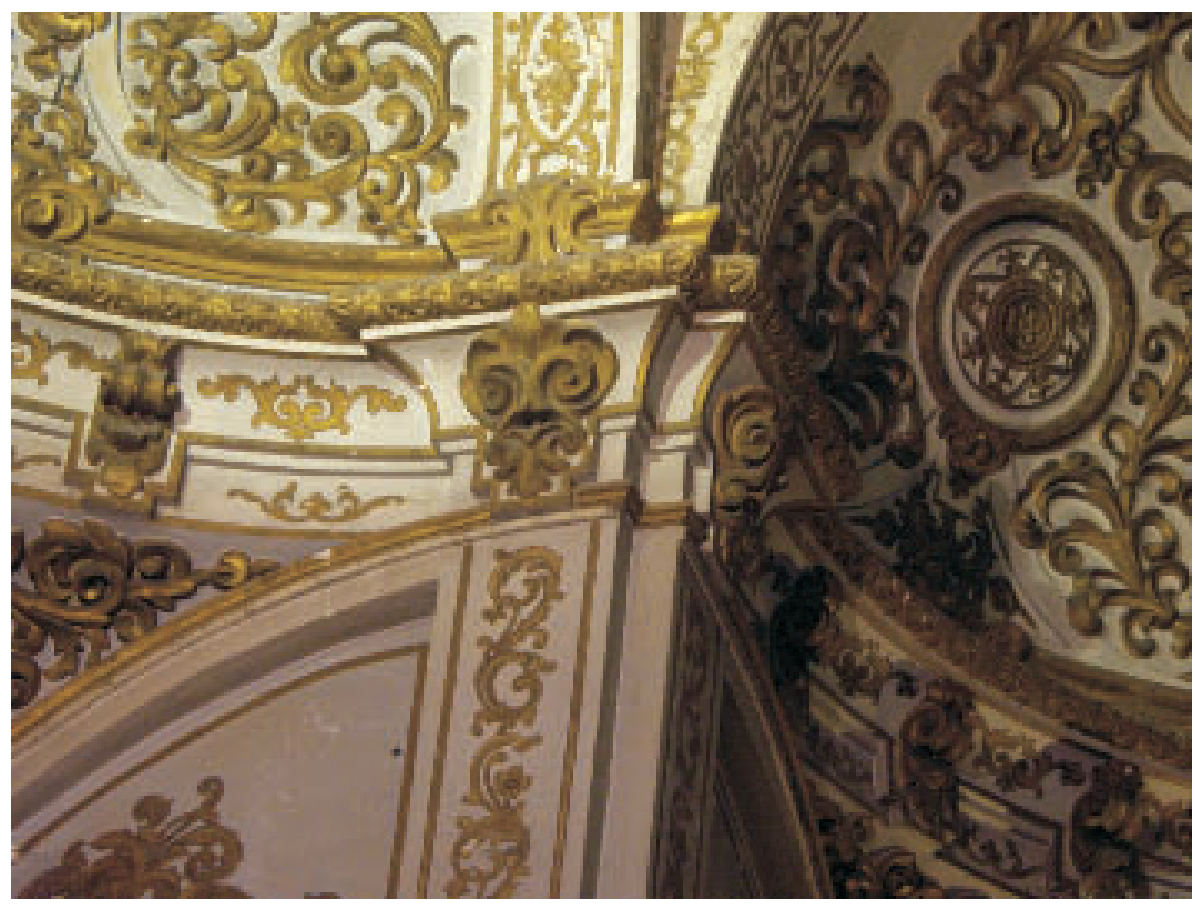

Fig. 7. Detalle de una pilastra con panel recortado y golpe de hojarasca al estilo canesco.

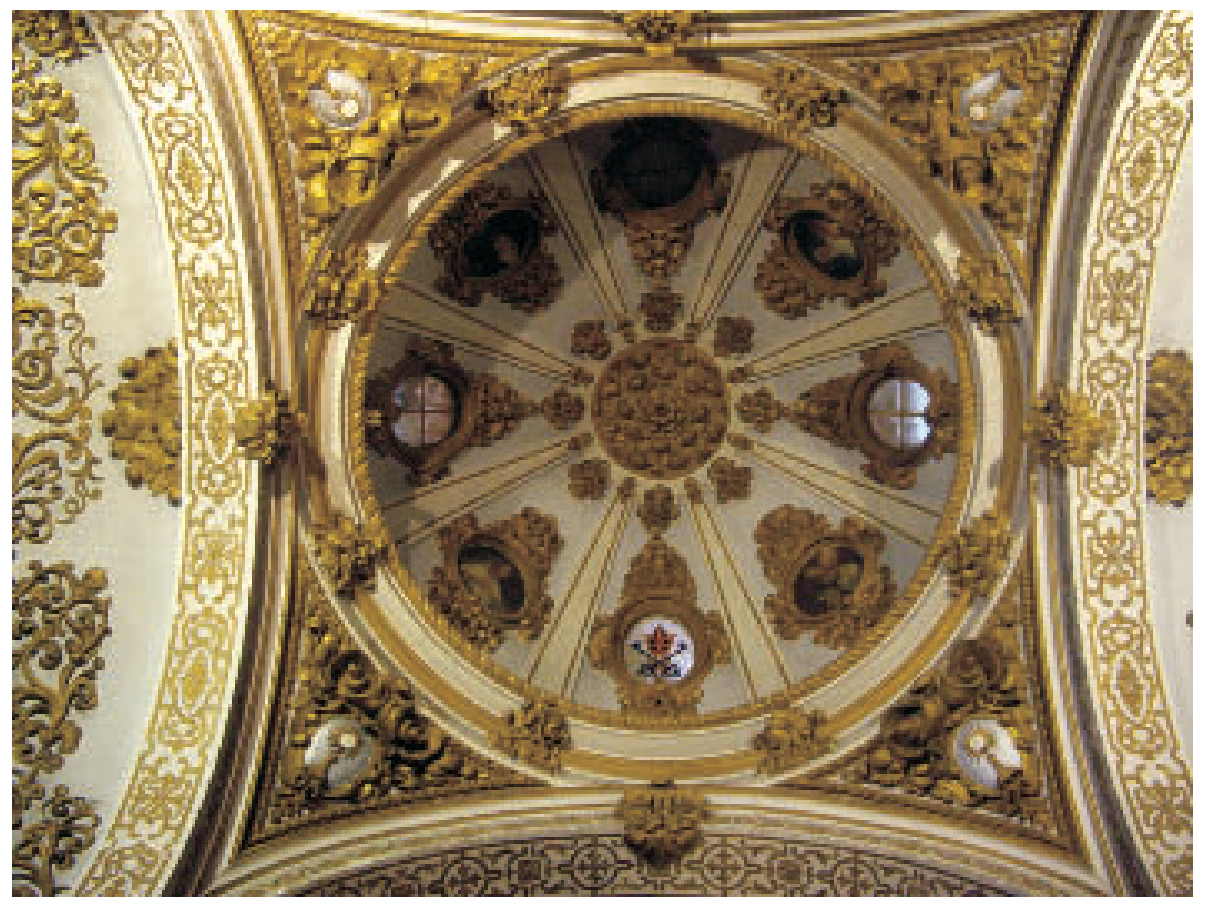

Fig. 8. Cúpula con las ornamentaciones de José Sánchez.

Arch. esp. arte, LXXXIV, 333, ENERO-MARZO 2011, 1-24, ISSN: 0004-0428 
"intrusismo" de ensambladores y pintores ${ }^{25}$. Pero tales críticas tienen un escaso valor en el Antiguo Régimen, un periodo en el que, como es bien sabido, las fronteras entre las artes eran permeables, no existía titulación de arquitecto y el artista con inventiva podía ejercer de tal delegando la construcción en maestros de obras.

La concepción de los espacios que tenía Cano es difícil de valorar, dado que se perdió la iglesia del Ángel Custodio, aunque la profundidad y juego de volúmenes de la fachada de la Catedral nos demuestran que Cano no era un mero decorador ${ }^{26}$. En el campo de la ornamentación sí tenemos un conocimiento más seguro de sus aportaciones. Lo más llamativo es la supresión de los órdenes clásicos y su apuesta por una ornamentación más abstracta, lo cual tiene precedentes en la arquitectura tardoescurialense de Castilla, pero que él lleva más lejos y con más imaginación. Además, es preciso destacar que Cano distinguió claramente entre los retablos y la arquitectura en sentido estricto, porque en aquellos sí mantuvo los órdenes mientras que en la arquitectura los suprimió por completo. Su arquitectura aparece así recorrida y articulada por molduras, paneles recortados, rehundimientos, pinjantes, etc. En algunos puntos concretos, como la clave de los arcos o para reemplazar los capiteles de las pilastras, sitúa enfáticos y carnosos golpes de hojarasca, que se inspiran no sólo en el típico acanto, sino en otras plantas como los cardos. Este recurso constituye un imaginativo desarrollo de ideas ya apuntadas en el manierismo italiano ${ }^{27}$.

En fin, la llegada a Granada de Alonso Cano tuvo un impacto que nadie ha discutido en los campos de la pintura y la escultura, irradiando su influencia a un área geográfica que abarca las provincias de Granada, Málaga, Almería y parte de Córdoba y Jaén. La revolución artística que produjo fue inmediata, intensa y duradera. Tuvo medianos discípulos en el área de la pintura (Juan de Sevilla, Pedro Atanasio Bocanegra...) y más brillantes en el campo de la escultura (Pedro de Mena, José de Mora...). Fueron legión los mediocres imitadores y las copias que se hicieron de sus obras hasta mediados del siglo XVIII.

Sin embargo, su influencia en el campo de la arquitectura ha generado división de opiniones en la historiografía, siendo considerada por unos renovadora e incluso crucial $^{28}$, o cuestionada por otros, que reparten sus innovaciones entre artífices que nunca despertaron la admiración de nadie en su tiempo ni dejaron recuerdo. Es indudable que Cano llegó a Granada con una voluntad innovadora muy grande en el campo de la arquitectura y del retablo, que hizo proyectos, que fue consultado y que sus dibujos con fantasías ornamentales circularon. Además se percibe una rápida evolución de la arquitectura granadina y de su entorno desde que él llega a la ciudad. El problema reside en la complejidad y lentitud de todo proceso constructivo, el cual queda reflejado en escuetos, confusos y fríos documentos de archivo que oscurecen o incluso ocultan la

${ }^{25}$ Corpus canesco..., op. cit., p. 270 y Blasco Esquivias, B., "Consideraciones sobre la universalidad de Alonso Cano (1601-1667) y su fama de arquitecto", Anales de Historia del Arte, 15 (2005), 127-150, pp. 148-149.

${ }^{26}$ Es muy amplia la bibliografía que a partir del Archivo de la Catedral de Granada analiza esta obra y reafirma la autoría de Cano, delimitando los añadidos que no corresponden a su diseño. No obstante, hay quien sigue planteando interrogantes, como MARÍAS FranCo, F., "Sobre Alonso Cano arquitecto: obras, dibujos y dudas", en Alonso Cano y su época, Granada, Junta de Andalucía, 2002, pp. 197-200.

27 Creo que el cuestionamiento -sólo parcial- que en 1975 hizo Taylor de la autoría canesca de estos "caprichos" vegetales (Taylor, op. cit., pp. 7-8) ha sido desmentida por los dibujos del racionero que se han ido conociendo con posterioridad. La gran mayoría de la historiografía respalda el uso por Alonso Cano de estos elementos vegetales, visibles, por otra parte, en los retablos que de él conservamos.

${ }_{28}$ Valoraciones muy altas de la figura de Cano como arquitecto en dos trabajos clásicos: KuBLER, G., Arquitectura de los siglos XVII y XVIII, Madrid, Plus Ultra, 1957 (Ars Hispaniae), pp. 86-90, ChueCA GoITIA, F., Historia de la Arquitectura española. Edad Moderna y Contemporánea. Tomo II, Ávila, Fundación Cultural Santa Teresa, 2001, pp. 309-314. Véanse, por otra parte, las recientes aportaciones de BÉRCHEZ GómEZ, J. y RodríGuez Ruiz, D. recogidas en Alonso Cano y su época, Granada, Junta de Andalucía, 2002. 
autoría del proyecto, y lo diluyen en la multitud de artífices que desfilan por toda obra a lo largo de los años. En realidad la mayoría de las personas se limitan a ejecutar un proyecto y, si bien es cierto que los artífices más cualificados pueden introducir cambios a petición de los comitentes, si no hay una petición expresa por parte de éstos, la obra final responderá al diseño original, aunque sea de manera deslucida.

El edificio que sirvió de escuela para los discípulos y emuladores de Alonso Cano fue el convento del Ángel Custodio, iniciado y acabado en vida de Cano. Nunca lamentaremos bastante los historiadores su demolición por las tropas napoleónicas en 1810. Para colmo, no tenemos ni planos, ni vistas, ni dibujos de sus ornamentos, y hemos de conformarnos con una descripción. Si ese edificio hubiera llegado hasta nosotros, aunque fuera a través de imágenes, sería posible medir hasta qué punto los seguidores de Cano fueron meros continuadores o tuvieron fuerza creativa.

Aparte de la fachada de la Catedral, realizada tras su muerte, el edificio más brillante que poseemos en la línea abierta por Cano es el convento de agustinas recoletas del Corpus Christi (hoy también conocido como de la Magdalena) en la calle de Gracia, sorprendente iglesia de José Granados de la Barrera que suele considerarse una variante de la desaparecida iglesia del Ángel Custodio. Aunque René Taylor destacó la creatividad de este arquitecto de origen cordobés en detrimento de un Alonso Cano a quien consideraba mitificado, en mi opinión no parece convincente que un maestro cantero de reducida trayectoria y poco conocimiento de la arquitectura más allá de Cabra y Granada inventara un estilo tan complejo como el de la iglesia de agustinas recoletas, cuya planta, por otra parte, tiene precedentes madrileños. La hipótesis tradicional de que se inspiró en la iglesia del Ángel Custodio sigue pareciéndome válida a pesar de las pegas de Taylor ${ }^{29}$.

Pero hay otros edificios de fuerte impronta canesca menos valorados y con un común denominador, la presencia de Juan Luis de Ortega, o sea, de la persona que mejor conocía el estilo de Alonso Cano. Esos edificios son la basílica de las Angustias, el poco conocido templo de la Encarnación de Laujar del Andarax y el templo de Hospitalicos.

\section{Primeros trabajos e incorporación de Juan Luis de Ortega}

Como hemos visto, el 5 de agosto de 1654 se puso la primera piedra de la iglesia del hospital del Corpus Christi. De inmediato fueron adquiridos diversos materiales (piedra de Alfacar, cantos rodados del Darro, arena del río Beiro, ladrillos...) y hasta finales de año se allanó el solar, se retiró un pilar de agua, se establecieron los cimientos y se comenzaron a elevar unos machones. Los artífices que trabajaron en la primera fase de la obra fueron mu-

\footnotetext{
${ }^{29}$ Sobre este arquitecto y este edificio véase TAYLOR, op. cit., pp. 10-12 y 15. También es de interés, por aportar datos inéditos sobre la trayectoria inicial de José Granados, el trabajo de Moreno RomerA, B., "José Granados de la Barrera y Melchor de Aguirre. Arquitectos de las obras de la catedral de Granada en la segunda mitad del siglo XVII. Importancia de las labores del mármol en el barroco andaluz", en La Andalucía de finales del siglo XVII, Cabra, Ayuntamiento de Cabra, 1999, pp. 150-156. Aunque Taylor señala que Cano no podía tener ninguna relación con un edificio que se empezó a construir en 1677, lo cierto es que las monjas eran propietarias de una parte del solar en el que se edificaría en 1667, el año de la muerte del racionero, y ya tenían intención de comprar las casas anexas. Sobre la fundación del convento véase García Valverde, M. L., "Fundación y consolidación del convento del Corpus Christi de Granada: 1655-1699", en Actas del Congreso sobre la Andalucia de finales del Siglo XVII, Cabra, Ayuntamiento de Cabra, 1999, pp. 399-416 y Justicia Segovia, J. J., "El convento del Corpus Christi de Granada, cuna de las agustinas recoletas en Andalucía", en Los agustinos recoletos en Andalucía y su proyección en América. Actas del I congreso histórico, Granada, ARPSTV, 2001, pp. 137-150.
} 
chos, el más conocido de los cuales es el maestro Juan de Rueda, que hacía el seguimiento de las obras. Los demás artífices que vemos en los trabajos son canteros (Antón Marín y Martín Falconete ${ }^{30}$ ) o maestros de los que no se indica su especialidad ${ }^{31}$. Todos ellos trabajan durante 1655 en el levantamiento de un muro que aislara el solar de la "calleja" (la hoy denominada calle del Hospital del Corpus Christi), y en la cimentación y colocación de unas pilastras con la ayuda de nueve peones ${ }^{32}$. Pero las obras fueron perdiendo fuelle hasta quedar paralizadas $^{33}$, y en los años siguientes sólo se acometen algunas actuaciones puntuales en el hospital viejo ${ }^{34}$.

El 24 de octubre de 1658 el maestro de albañilería y veedor de las obras del arzobispado Juan Luis de Ortega ingresa en la hermandad -todavía era hermano mayor Pedro de Mena ${ }^{35}$ - y permanecerá en ella hasta su fallecimiento el 22 de junio de 1677. Durante ese periodo fue dos veces mayordomo, dos veces hermano mayor, otras dos oficial y también sirvió como escribano de la hermandad. Ortega destacó además por dar diferentes limosnas a la hermandad, perdonar deudas que ésta tenía con él y legar cien reales en su testamento. En la iglesia fue enterrado su suegro, su esposa y más tarde él mismo; su hijo, el sacerdote Francisco Antonio de Ortega, ocupará su plaza en la hermandad ${ }^{36}$. Con tan larga y entregada trayectoria, cabe imaginar el interés con el que impulsó las obras de la iglesia, a las que indudablemente dio el sello estilístico de Alonso Cano, a quien seguramente pidió consejo en más de una ocasión para esta obra, pues el racionero siempre fue generoso en darlos e incluso en hacer bocetos para que otros los ejecutaran ${ }^{37}$.

Juan Luis de Ortega realizó una intensa labor constructiva durante el tercer cuarto del siglo XVII. Siguiendo trazas de Alonso Cano edificó la iglesia del Ángel Custodio entre 1653 y 1661. Contra lo que era habitual, a esta iglesia se accedía por el costado meridional, donde se ubicaba un pórtico con tres arcos de piedra negra y un nicho sobre el arco central presidido por la imagen en mármol del titular. El interior de la nave no guardaba "las comunes reglas de la Arquitectura, sino que la ingeniosidad del Artificie inventò una nunca executada forma". Se componía de una única nave con tres tramos más la capilla mayor, separados éstos por pilastras sin capitel. En ellas apoyaba una imaginativa cornisa sobre la cual se abrían las ventanas que iluminaban la nave. En el crucero cuatro pilastras sostenían una cúpula ornada con fajas e iluminada por cuatro ventanas. A la izquierda del transepto se ubicaba el coro bajo de las monjas y a la derecha un retablo. Cuatro grandes nichos con esculturas completaban la decoración del cru-

30 Martín Falconete era vecino de Alfacar y lo vemos en 1666 y años sucesivos pagando un censo a la hermandad (AHCC, L-41). Este maestro es citado en otras obras de la ciudad en GILA MEdiNA, Maestros de cantería..., op. cit., pp. 129-130.

${ }^{31}$ Las cuentas citan a Diego Miguel, Pedro Gallardo y Juan Bermejo sin precisar sus tareas. También a Francisco José que evacua buena parte del cascajo, Antón López Calero que entrega cal, el cochero de caminos P. Bermejo que deja cuatro mulas para traer piedra de Fuente de la Teja, etc. AHCC, L-31.

32 AHCC, L-31.

${ }^{33}$ La mayoría de las actividades se desarrollaron en el campo de la albañilería. Entre los nombres que se mencionan en las cuentas (AHCC, L-31) hay un tal Manuel Rodríguez que posiblemente sea un maestro albañil, pues con ese nombre se cita uno activo en esas fechas en Gila Medina, Maestros de cantería..., op. cit., p. 518.

${ }^{34}$ En 1657 se habla de una reparación del hospital "por el lado de la obra". AHCC, L-31.

35 Pedro de Mena se había marchado a Málaga unos meses antes (Gila Medina, Pedro de Mena..., op. cit., p. 48), pero seguía ocupando formalmente este puesto, quizás porque todavía se dudaba si su partida sería definitiva.

36 AHCC, L-29 y L-39.

37 "También hacía diseños para las obras que se encargaban a sus discípulos, y se divertía muchas veces en dibujar sin destino determinado, que concluía con suma gracia y limpieza". Palabras del "Diccionario" de CeÁn BERmúdEZ, en Corpus canesco..., op. cit., p. 562. 
cero. A los pies de la nave se encontraba el coro alto y bajo éste una tribuna dedicada a la música "con rexas de bien labrado hierro". Todos los elementos decorativos (volutas, follajes, cartelas...) eran propios del peculiar estilo de Alonso Cano ${ }^{38}$.

Más adelante Juan Luis de Ortega fue el veedor de las obras de la basílica de las Angustias, templo que se edificó entre 1663 y 1671 -la portada de piedra, el camarín, las torres y la cúpula son posteriores-, y cuya traza realizó otro maestro de obras implicado en la construcción de Hospitalicos, Juan de Rueda Moreno ${ }^{39}$. Aunque la planta de esta iglesia sigue el modelo trazado por Vignola para Il Gesú de Roma, tan imitado en Granada, algunos aspectos de la ornamentación tienen clara relación con el lenguaje de Alonso Cano.

El siguiente proyecto en el que vemos implicado a Juan Luis de Ortega es ya posterior a la muerte del racionero. Se trata de la iglesia de la Encarnación de Laujar del Andarax, un edificio que rompía con la monótona tradición de iglesias mudéjares de las Alpujarras ${ }^{40}$. La primera piedra se puso el 21 de noviembre de 1672 y, siguiendo un proyecto de Ortega, los trabajos los dirigió el alarife granadino Diego González hasta la inauguración del templo en 1686. La planta es de cruz latina con nave única, capillas entre los contrafuertes interiores, bóveda de medio cañón con arcos fajones y lunetos ciegos, balcón corrido en la cornisa y, en el crucero, una media naranja con ventanas ovaladas. La capilla mayor es plana y se abren a ella dos tribunas con rejas de hierro y bajo éstas unos balcones cóncavo-convexos. El templo es sobrio y luminoso, con decoración de molduras en la cúpula, golpes de hojarasca en las bóvedas, y paneles recortados y caprichos vegetales dorados reemplazando a los capiteles de las pilastras. Aunque la planta es muy distinta a la de Hospitalicos, otros elementos presentan claras relaciones: la decoración, las ventanas ovaladas de la cúpula, los vanos tripartitos, las portadas de ladrillo y la torre. Más adelante volveré sobre estas similitudes.

\section{Continuación de las obras en Hospitalicos}

Las obras de Hospitalicos estuvieron paralizadas, salvo algunas intervenciones de poco alcan$\mathrm{ce}^{41}$, hasta que el 23 de marzo de 1662 Juan Luis de Ortega comienza a trabajar con la colaboración del maestro Juan de la Peña y varios peones en una capilla para el Santo Cristo de la Columna. Esta capilla está en el punto de confluencia entre el viejo hospital y la nueva iglesia en construcción, con la probable intención de que quedara incorporada a ésta una vez concluida.

38 Thomas de Montalvo, Fr., Vida prodigiosa de la extatica Virgen, y venerable madre sor Beatriz María de Jesús, Abadesa, que fue del convento del Ángel Custodio, de la Ciudad de Granada de Religiosas Franciscas Descalças de la más estrecha observancia de la Primera Regla de Santa Clara: Chronica del mismo convento y memoria de otras Religiosas insignes en virtud, Granada, Francisco Dominguez, Impressor, 1719, pp. 426-427.

${ }^{39}$ Gómez-Moreno González, Guía..., op. cit., vol. I p. 236 y vol. II p. 133. El primitivo retablo, muy marcado por el lenguaje de Cano, sabemos con certeza que es de Bernardo de Mora y se realizó entre 1667 y 1671 (Gila MedinA, L., "Sobre el antiguo retablo de Ntra. Sra. de las Angustias -hoy en Santa María de la Alhambra- de Granada, obra inédita de los Mora", Cuadernos de Arte, 27 (1996), p. 74).

${ }^{40}$ La atribución de esta iglesia a Juan Luis de Ortega en Torres FernÁndeZ, M. R., "Arquitectura eclesial y retablística de los siglos XVII y XVIII”, en La Almería barroca, Almería, Junta de Andalucía, 2008, pp. 50-51. La ejecución a cargo de Diego González, que falleció en 1708 en Laujar, y otros datos interesantes sobre su construcción en PUERTAS García, A., El templo de Laujar del Andarax (1686-1986), Almería, Cajalmería, 1986.

${ }^{41}$ En 1659 se habla de "quitar los ladrillos de la iglesia para el jueves santo". Al año siguiente hay gastos por evacuación de cascajo y compra de ladrillos y madera, se contrata a carpinteros, un maestro albañil o cantero y varios peones, pero no queda claro el objeto de los trabajos, que lo mismo consistían en remozar el viejo hospital. AHCC, $\mathrm{L}-40$.

Arch. esp. arte, LXXXIV, 333, ENERO-MARZO 2011, 1-24, ISSN: 0004-0428 
Los trabajos de esta capilla se hicieron con celeridad y pronto se colocó un colgadizo que parece tenía adornos de yeso ${ }^{42}$.

Lo limitado de los recursos ${ }^{43}$ hace que hasta 1665 no comience una intensa campaña de trabajos. Las noticias sobre qué es lo que se realiza son confusas, pues cuando se habla de las dependencias del hospital no sabemos si se hace referencia al antiguo o al nuevo ${ }^{44}$. En cualquier caso se avanza en la construcción de la iglesia, y se pagan "dos columnas grandes y pilastras de piedra dura de la sierra de Elvira que están puestas en el primer cuerpo de la dicha iglesia del dicho hospital" ${ }^{45}$. Entre las personas que trabajan en estas fechas está el maestro de carpintería y miembro de la hermandad Luis Serrano, que coloca las armaduras de las nuevas dependencias ${ }^{46}$. La progresión de los trabajos es tal que en 1668, un año después de la muerte de Juan Luis de Ortega, se "rompió [superó] el arco de la capilla nueba y cubrio la dicha capilla"47. No sabemos con certeza cuándo se empezó a utilizar la nueva iglesia y cuándo quedó cerrada la antigua, pero esto debió ocurrir a más tardar una década después.

Por otra parte, en 1677 se habían "gastado en la obra de la portada de nuestro hospital mil trescientos y nueve reales". Lo más probable es que se refiera a la portada de piedra gris que da acceso al hospital por la calle Calderería Vieja, que es muy sobria y luce en su dintel el escudo de la orden dentro de un capricho vegetal canesco ${ }^{48}$. Al año siguiente fue remozado el viejo hospital y completadas las nuevas dependencias por dos artífices que eran hermanos de la cofradía, el maestro de albañilería Francisco Muñoz y el ya citado maestro de carpintería Luis Serrano ${ }^{49}$.

Gracias a un inventario realizado en 1680 sabemos de una manera aproximada que fisonomía presentaba la nueva iglesia y algunas dependencias anexas de reciente construcción ${ }^{50}$. Sobre la puerta de la iglesia, protegido por un guardapolvo con un gran farol, había un nicho que albergaba un Crucificado de talla, y bajo él una inscripción, todo lo cual había sido hecho o renovado dos años antes. Esto demuestra que la portada de piedra trazada por Cano no se había labrado aún. Además, una parte del edificio no tenía tejados, sino una azotea, lo cual suscita la pregunta de si el templo había sido concebido sin ellos o si éstos se hicieron necesarios más adelante para

\footnotetext{
${ }^{42}$ Se colocaron también dos bancos en la capilla labrados por Sebastián de Vílchez. También se hizo un recorrido de los tejados del hospital, y al año siguiente nuevas labores de mantenimiento. AHCC, L-40.

43 En 1663 se recauda entre los hermanos dinero para la obra de la capilla del Sto. Christo. Algunos hermanos en lugar de dinero dan objetos o trabajan una jornada. AHCC, L-41.

${ }^{44} \mathrm{La}$ importancia de los trabajos queda fuera de duda por el alcance de los gastos. Entre las confusas noticias puede recogerse ésta de 1666: "para dar principio a la obra trajo por horden de Juan Luis de Ortega un maestro y dos peones que trabajaron tres dias en quitar el altar de nuestra señora y desbaratar la capilla y en remeterla más hacia la iglesia para desembaraçar sitio para principiar la obra y asi mesmo otras cosas que fueron menester en la sala de la enfermeria y aliñar la escalera" (AHCC, L-40). También hay noticias sobre la recolección de "limosnas para la obra de la Capilla del Sto. Cristo de la Columna" (AHCC, L-41).

${ }^{45}$ En 1667 se vende "material viejo de la obra" (o sea, material de derribo) para trabajos en las casas de la Inquisición a la par que hay gastos en piedra, arena y ladrillos. También se habla del pago de 6 peones para la obra. AHCC, L-41 y L-56.

${ }_{46}$ Algunos días Luis Serrano trabaja "de limosna", otros cobra, al igual que hace un maestro de albañilería cuyo nombre no se da. Con ellos trabajan hasta el final de 1667 un oficial y varios peones. AHCC, L-40.

${ }^{47}$ En ese momento era mayordomo el alfarero Bernabé de Castro, que ingresó en la cofradía en 1663 con un generoso donativo y falleció en 1701. En la ficha de su fallecimiento es en la que se da la fecha de la conclusión de la cúpula. AHCC, L-29.

48 AHCC, L-40.

${ }^{49}$ Las obras, de las que hay una prolija descripción, concluirían en 1679, cuando se compran ladrillos para solar la capilla mayor de la iglesia nueva. AHCC, L-43.

50 Según los hermanos: "hallamos tan confusos y obscuros los Inventarios y hacienda de nuestra hermandad que nos motivó con gran trabajo nuestro a hacer nuebos inventarios". AHCC, L-42.
} 
una mejor evacuación de las aguas. Entre los documentos del archivo que se citan en el inventario está la escritura de una casa que la hermandad posee arrimada al hospital. Esta casa será derribada en 1685 para permitir la construcción del campanario. Entre tanto se sigue utilizando la pequeña torre del oratorio antiguo.

El interior del templo está totalmente acabado desde el punto de vista arquitectónico, pero carecía de los ornamentos de yeso que hoy vemos. En el suelo hay esteras y en las paredes lienzos y modestos altares cuyas advocaciones no coinciden en algunos casos con las que tendrán los retablos del siglo XVIII. La capilla mayor era modesta, sin mármoles policromos ni yeserías. En 1681 se añadió un púlpito donado por un hermano ${ }^{51}$.

La tribuna no contaba con la reja de hierro que hoy vemos, sino con una celosía de madera. La tribuna linda con la nueva sala del Cabildo, la cual pisa sobre los pies del templo y tenía su propio altar, una mesa de nogal para las reuniones y unas alacenas con el archivo de la hermandad. La tribuna permitía pasar a la "enfermería nueva", donde había mesas y sillas para que comieran los enfermos y un altar recién terminado. Al lado se ubicaba una alcoba con dos camas separadas por una cortina.

\section{Terminación del edificio (1685 a 1692)}

Tras una pausa de siete años, en 1685 se inicia el derribo y desescombro "de la obra vieja" o antiguo hospital y de la casa adyacente adquirida tiempo atrás ${ }^{52}$. Entretanto, los hermanos piden dinero por las calles, celebran rifas y comedias, o venden materiales viejos de construcción que no son útiles ahora ${ }^{53}$. Con el dinero compran piedra de Alfacar, grandes cantidades de ladrillo, madera, cuerdas para los andamios, etc. Los derribos se van haciendo por etapas, quizás porque no se puede prescindir simultáneamente de todas las antiguas dependencias y hay que esperar a que otras nuevas estén disponibles. Cinco años después terminan de demolerse las dependencias del hospital viejo, entre ellas la vivienda que ocupaba el hermano mayor ${ }^{54}$. En las partes del solar que van quedando despejadas se colocan cimientos en los que se usa arena y almendrón ${ }^{55}$.

Las tareas pendientes son múltiples: construir una nueva torre, hacer la portada del templo, decorar las bóvedas, reemplazar las viejas dependencias del hospital por otras nuevas... Para toda esta fase de obras que se inicia contamos con las cuentas de gastos de los años 1685 a 1692, pero todo indica que los trabajos continúan más allá de estas fechas. Aunque los datos sobre cuáles son las tareas que se realizan son muy poco precisos, en las siguientes páginas haré una exposición lo más clara posible del desarrollo de los trabajos.

${ }^{51}$ Este púlpito fue donado por el hermano Francisco Gálvez y es la principal novedad que arroja un breve inventario de 1681, AHCC, L-42.

${ }^{52}$ Los derribos se realizan con suma lentitud, a medida que es necesario despejar los solares; todavía hay labores de desescombro en 1692. Todo indica que lo primero que se derribó fue la casa, pues sobre su solar se edificó la nueva torre. El hospital viejo sería derribado más adelante para edificar dependencias nuevas. AHCC, L-56 e inventario de 1701 en L-42.

${ }^{53}$ La piedra de Alfacar la proporciona Francisco de Pineda. Difícil de interpretar es la petición de dinero al hermano José Vidal para "una talla para las plantillas". Gastos de 1685, AHCC, L-56.

54 Debido a las obras del hospital se han quedado sin la vivienda que ocupaban el hermano Antonio y su madre, lo que obliga a pagar el alquiler de una casa para ellos. Gastos de 1689, AHCC, L-56.

55 Bartholomé Barcala trae la arena y el almendrón y, en el mismo carro que trae materiales, se lleva cascajo. A Francisco Ramírez y a Pedro Méndez se les paga por la cal, a Diego Rodríguez y Manuel García, vecinos de Gabia, por las tejas, ladrillos y canes; Alonso Rodríguez yesero muere ese año y a partir de entonces los pagos se hacen a su viuda. Gastos de 1689, AHCC, L-56. 
Tras las tareas de derribo iniciales el principal reto es recaudar dinero, de manera que durante año y medio los trabajos quedan detenidos antes de volver a reanudarse con toda intensidad. Por fin en 1687 la iglesia es sometida a una reforma importante que sin duda alteraba el proyecto original. Para empezar, en abril son colocadas columnas y pilastras de piedra de Elvira en los pies del templo, en los cuales ya había dos columnas de piedra gris que quizás resultaron demasiado delgadas para soportar el peso de los tejados que se iban a añadir ${ }^{56}$. Además, dos medias columnas de piedra fueron añadidas a las pilastras sitas bajo la tribuna. De esta manera se configuraban de manera coherente dos ambientes, el de los pies del templo, bajo y con columnas de piedra de Elvira de orden toscano, y la diáfana cúpula con sus medias cúpulas, apoyadas en altos pilares sin órdenes clásicos.

No se menciona el nombre del cantero que labra estas columnas, pero debe de ser Francisco de Cárdenas ${ }^{57}$, el mismo que hace la "portada de adentro", o sea, la del nártex ${ }^{58}$. Entretanto se compra "piedra blanca de la de Alfacar" a la Catedral, que debe tener una remesa sobrante. Además sabemos que en 1690, aparte del cantero Francisco de Cárdenas, hay contratados un escultor y un bruñidor. Todo esto podría indicar que se está labrando la portada de la iglesia, que combina piedras gris y blanca, y requería trabajos específicos de escultura.

En la tribuna o "balcón redondo" Francisco de Cárdenas coloca cuatro pequeñas columnas toscanas de piedra de Elvira. Además se retira la antigua celosía de madera y se pone una balaustrada de hierro que hace el maestro cerrajero Juan Díaz. Esta reja es rematada con unas bolas de piedra rosa de Alfacar que labra una vez más Francisco de Cárdenas ${ }^{59}$.

La torre empieza a edificarse hacia 1687 y a ella están destinadas en buena parte las grandes cantidades de ladrillos, cal y yeso que se adquieren aquel año ${ }^{60}$. En 1689 el cantero Francisco de Cárdenas cobra por piedra de Elvira que trae para las bolas y asientos de la veleta del campanario $^{61}$, y al año siguiente coloca la cornisa de piedra valiéndose de unos costosos andamios ${ }^{62}$. En paralelo se ponen tejados al cuerpo de la iglesia, para lo cual se adquiere madera de pino y tejas, y se contrata al maestro carpintero Blas Martínez ${ }^{63}$. Sobre la capilla mayor los tejados tienen caballetes con tejas vidriadas.

Una vez asegurada la protección del templo contra la lluvia, se contrata a un maestro tallador de yeso para que orne la iglesia. La persona elegida es José Sánchez, oriundo de Iznalloz. Tras

${ }^{56}$ Hay una noticia sobre la venta de una columna a un tal Bermejo, probablemente una de las retiradas, AHCC, L-56.

57 La documentación del archivo de Hospitalicos parece indicar que este maestro cantero es oriundo de Alfacar, aunque tampoco lo afirma con claridad. De la existencia de este cantero se da noticia en GiLA Medina, Maestros de cantería..., op. cit., p. 116.

58 Gastos del año 1687, AHCC, L-56.

59 La reja y las bolas se colocan en 1692. AHCC, L-56.

${ }^{60}$ Pagos a Diego Rodríguez por la entrega de enormes cantidades de ladrillos y tejas, también se habla de Alonso Rodríguez como suministrador de yeso, de un arenero llamado Romero, de los pinos que se compran a Manuel Díaz, de la "madera ordinaria" de los andamios que se trae del Soto, etc. Gastos del año 1687, AHCC, L-56.

${ }^{61}$ Que la obra de la torre está próxima a concluirse queda también de manifiesto en los gastos para colocar una tinaja de agua en el llamado cuarto de la torre y por la adquisición de cordeles para la campana. Gastos de 1689, AHCC, L-56.

62 Hay noticias de otros trabajos de cantería de menos relevancia: Francisco de Cárdenas trae dos columnas para "los dos balcones" (se refiere sin duda a las ventanas tripartitas). En 1691 el mismo Francisco de Cárdenas cobra por unos escalones de piedra que trae "y por su trabajo personal"; también por piedras para la entrada de la torre. En 1691 un oficial hace el escalón de entrada de la sala del cabildo y luego es bruñida. AHCC, L-56.

${ }^{63}$ Entre otras cosas Blas Martínez cobra por "poner la madera y armar los colgadizos de los lados de la torre". La piedra para la cornisa, sin duda de Alfacar, la suministra Francisco Pineda. A Diego Vellón se pagan ciento diez tejas vidriadas para los caballetes. Gastos de 1689 a 1691, AHCC, L-56. 
unas semanas de trabajo José Sánchez y un miembro de la hermandad reconocen los trabajos hechos: "flores, molduras y caprichos en todas las bóvedas y lumbreras de la media naranja y colaterales de la capilla mayor", por lo cual cobra 600 reales. El trabajo de José Sánchez continúa en 1691 en "los cascos de la media naranja de la capilla mayor" y en la escalera de la torre, donde hay una media naranja de colgadizo; además realiza unos "golpes" para la sala capitular. Las yeserías son fijadas en las bóvedas con clavos.

José Sánchez trabaja ayudado por cuatro peones y en ocasiones por un oficial carpintero. El maestro cobra 9 reales por día, el oficial 6 y los peones $4^{64}$. José Sánchez es también el autor de las yeserías de la iglesia del convento de Agustinas Recoletas en la calle de Gracia y posiblemente de las yeserías de la capilla mayor de la iglesia de Santo Domingo ${ }^{65}$. Las ornamentaciones de José Sánchez están en la línea de los adornos que aparecen en los edificios de Alonso Cano y Juan Luis de Ortega, pero son más profusos. Podría decirse que este maestro tiene un estilo derivado de modelos canescos, pero aproximándose por su exuberancia al gusto tardobarroco.

Además de las mejoras en las dependencias situadas sobre los pies del templo ${ }^{66}$, en $1690 \mathrm{se}$ comienza a trabajar también en la construcción de las dependencias nuevas del hospital a espaldas de la iglesia ${ }^{67}$. Sin embargo, en 1692 las obras en este sector están lejos de haber concluido, como prueba la apertura de nuevos cimientos ese año y que en los siguientes haya noticias muy vagas sobre trabajos ${ }^{68}$.

En fin, entre 1685 y 1692 los trabajos han sido muy amplios (cantería, albañilería, carpintería y decoraciones de yeso), lo que plantea dos preguntas: ¿Algún artífice se ha encargado de coordinar todos estos trabajos? ¿Cada maestro trabaja en su oficio, bien siguiendo un proyecto que marca con claridad las líneas generales del conjunto, bien a su libre albedrío? ${ }^{69}$

\footnotetext{
${ }^{64}$ A José Sánchez se le regala además un turrón por Navidad. Como suministrador de yeso se cita a Alonso Rodríguez. Gastos de 1691, AHCC, L-56.

${ }^{65}$ El origen de José o Joseph Sánchez es mencionado en AHCC, L-56. Taylor le añade un apellido que yo no he visto en el archivo de Hospitalicos: José Matías Sánchez (TAYLOR, op. cit., p. 14). En 1700 se cita a un maestro carpintero llamado Joseph Sánchez como una de las personas que informa sobre la seguridad de la cúpula oval de la Catedral de Granada, la cual tenía problemas estructurales y finalmente fue suprimida (RosenthAL, E. E., La catedral de Granada, Granada, Universidad de Granada, 1990, pp. 59 y 254).

${ }_{66}$ Ya se han indicado las yeserías que hace José Sánchez, a lo que hay que indicar otras tareas: A Felipe de Castañeda se le compran dos ventanas para la sala y antesala capitular; Blas Martín cobra por puertas, postigos y otras obras; un nuevo hermano da como luminaria una puerta de pino y nogal para la antesala capitular; Miguel Jiménez pone una solería en una de las salas, trabajando por las tardes y a la luz de las velas. AHCC, L-56.

${ }^{67}$ Hay elevados gastos en ladrillo, arena y cal, además de madera para una "armadura nueva". Como suministrador de ladrillos, incluidos ladrillos cortados, se cita a un tal Diego Rodríguez, del pueblo de Gabia, sin que se aclare si también los coloca. Con ese nombre hay un maestro albañil activo en Granada durante esos años (GILA MedinA, Maestros de cantería..., op. cit., p. 511). La arena la trae Bartolomé Barcala. Francisco Rodríguez, de Gabia, vende ladrillos. Trabaja de limosna un albañil llamado Joseph de Sevilla. Gastos de 1690 y 1691, AHCC, L-56.

${ }_{68}$ Algunos hombres que ingresan en la hermandad entre 1693 y 1696 dan dinero para ayudar a la obra sin que se especifique nada más, ni veamos intervenciones de maestros y peones de ningún tipo en los libros de la hermandad. En 1694 entra como hermano el maestro de albañilería Juan de Latorre, cuya "cuota" de ingreso es trabajar en una "bóveda grande de la obra nueva”, quizás una ampliación de la cripta (AHCC, L-39). En 1699 un nuevo hermano llamado Alonso López da un pasamanos de hierro para la escalera (AHCC, L-29).

${ }^{69}$ En la documentación, sobre todo en el año 1691, se habla continuamente de "pagarle la semana" a Francisco Ramírez, pero su papel no queda claro y podría ser sólo alguien que evacua escombros o suministra materiales. AHCC, L-56.
} 


\section{Problemas estructurales}

En 1710, el año en el que se termina de poner una solería de piedra blanca y negro azulado a la iglesia ${ }^{70}$, aparecieron unas rajas que fueron tapadas y enlucidas. Se aprovechó también para asear toda la iglesia, poner unos escalones de piedra de Elvira y, posiblemente, trabajar en los mármoles policromos de la capilla mayor ${ }^{71}$. Los hermanos no se percataron de que las grietas que habían tapado eran el anuncio de problemas estructurales que con el tiempo se convertirán en el principal quebradero de cabeza de la Hermandad.

A principios de 1727 la iglesia presentaba serias señales de ruina en "un pilastrón que reúne los Arcos del Cuerpo de dicha iglesia". El 28 de abril de 1727 acudieron al templo José de Bada (1691-1755), "maestro maior de la obra de la iglesia del Sagrario desta ciudad", y Manuel Baldeperez (o Dalda Pérez), "maestro maior de las obras publicas della". Señalan en su informe que:

"la fabrica de la Santa Iglesia es falsa por defecto de su planta que esta contra todo Arte por no guardar los preceptos de Architettura, y que por esto se a originado haberse lastimado uno de los dos pilastrones sobre que carga la Capilla maior de suerte que si no ponen pronto remedio, acontecerá una gran ruina. Y que para su remedio es necesario demoler dicho pilastrón, enderezar todo lo que es de piedra dura y sobre ella continuar el dicho pilastrón de piedra de Alfacar, siendo cada hilada de una pieza, y que de ella misma salgan las [...] de los dos arcos que conducen a dicho pilastron, y para que quede con toda seguridad dicha iglesia es necesario a cada uno de los cuatro arcos que conducen a dicha pilastra, y a la de enfrente hacerle una rosca de hierro que pase por dentro de los salmeres de dichos arcos" $" 72$.

El gasto de la obra estimada por los maestros es de 7.000 reales, cifra muy abultada que en esos momentos está fuera del alcance de la hermandad. Por lo pronto los hermanos se movilizan para obtener limosnas y consiguen, por ejemplo, un donativo del arzobispo y otro del Ayuntamiento. Pero el apuntalamiento se retrasó hasta 1728, año en el que por fin se adquirió una gran cantidad de madera a Diego Morales y se montó el andamio ${ }^{73}$, solución provisional en tanto se reunía el dinero necesario para afrontar las obras de reparación. Lo que en principio parecía una situación transitoria, iba a prolongarse largo tiempo. Así, durante unos años el templo permaneció abierto a pesar del estorbo que suponían los apuntalamientos ${ }^{74}$. Pero el aspecto inseguro y desde luego nada estético que presentaba alejaba al público: "los fieles no frecuentan la iglesia de este hospital como otras veces", lo que "cada día redunda en maior detrimento desta Yglesia" 75 .

Ante la situación de parálisis se nombraron unos hermanos como comisarios encargados expresamente de impulsar el arreglo del templo, medida que no tuvo ningún efecto, porque en

${ }^{70}$ En 1707 se informa de la labra de la solería de la iglesia, sin que se aclare a qué parte del templo se refiere. El suelo anterior era de ladrillo y estaba esterado. En ella trabaja voluntariamente Pedro López, que es maestro de albañilería (AHCC, L-76). En 1710 se trabaja de nuevo en la conclusión de la solería (AHCC, L-52).

${ }^{71}$ La obra debía de acabarse antes de que finalizara el año. Noticia fechada el 17 de febrero de 1710. AHCC, $\mathrm{L}-42$.

72 Reunión del 27 de abril de 1727, AHCC, L-61. Sobre este problema estructural recoge la profesora Encarnación Isla la noticia de un donativo del Ayuntamiento para las obras (Isla Mingorance, E., José de Bada y Navajas, arquitecto andaluz (1691-1755), Granada, Diputación Provincial, 1977, p. 498).

73 Reunión del 18 de abril de 1728, AHCC, L-61.

74 Reunión del 6 de agosto de 1730, AHCC, L-61.

75 Reunión del 24 de junio de 1731, AHCC, L-61. 
1733 se denunciaba "lo indecente que se halla la Iglesia con el apuntalado". Se contrató entonces al maestro de albañilería Jerónimo de Palma, "alarife desta ciudad"76, al cual se entregaron madera, hierro, trece sillares y dinero para que en el plazo de cuarenta días comenzara la obra. El inicio de los trabajos supuso el traslado del culto a la sacristía, en donde se instalaron unos altares. Los trabajos se paralizaban de tiempo en tiempo por la falta de ingresos, y se reanudaban cuando las limosnas aportadas por los hermanos lo permitían. Los trabajos de reparación estaban casi concluidos en marzo de $1734^{77}$. De nuevo la falta de ingresos paralizó el remate de los trabajos, que no pudieron darse por finalizados hasta el último día del año 1735 y ello gracias a la generosidad económica de algunos hermanos ${ }^{78}$.

\section{Descripción analítica del edificio}

La portada de la iglesia, austera y de clara composición, con unos modestos 7 metros de altura, consta de un vano adintelado en el que las típicas columnas o pilastras que debían de flanquearlo son sustituidas por una original composición en el que la basa es un cubo moldurado, el fuste es sustituido por molduras interrumpidas por rosetones y el capitel por curiosos motivos vegetales. En el centro del dintel sobresale un escudo papal con símbolos eucarísticos. Sobre este escudo una hornacina con la Caridad (una mujer que ampara a tres niños), encima de la cual hay un golpe de hojarasca canesco y a los lados dos medallones con San Juan Evangelista y San Juan Bautista. Todo esto queda enmarcado por una moldura que forma medio círculo y sustituye, pues, al frontón clásico; esta gran moldura forma un arco que nos recuerda a los de la fachada de la Catedral granadina, pero sin la profundidad que les da un dramático contraste lumínico. Sin embargo, este diseño es anterior al de la Catedral y, por lo tanto, aquí encontramos ya apuntadas algunas ideas tales como el gran arco-ático o la supresión de los órdenes clásicos y su sustitución por un nuevo lenguaje. La portada es de piedra de Elvira con los ornamentos y esculturas en mármol blanco. Sin duda responde al diseño que dio Alonso Cano, pero la tosquedad casi naif de las imágenes desluce la indudable originalidad de su ideación ${ }^{79}$. Los precedentes de la portada los encontramos en la propia obra de Cano como ensamblador. El retablo de San Diego (Alcalá de Henares), que conocemos por un dibujo, tiene una composición que guarda clara relación con éste: el gran arco que enmarca el ático, el golpe de hojarasca en la clave de ese arco y el diseño de las ménsulas-hojarascas ${ }^{80}$.

La fachada que presenta el edificio a la calle Elvira exterioriza en sus 15 metros de longitud tanto la iglesia como algunas dependencias del hospital. Ello la hace poco usual, dado que sobre la portada hay un balcón que da luz a una sala sita sobre el nártex y presta un aire palaciego al

76 AHCC, L-61. Era maestro mayor de las obras de la ciudad y aparece citado en otras obras de la ciudad en GILA Medina, Maestros de cantería..., op. cit., pp. 218-220.

77 Para esta fecha se han invertido más de 5.000 reales y se trabaja en las puertas del templo. Reunión del 15 de marzo de 1734. AHCC, L-61.

78 Reunión del 30 de diciembre de 1735 . AHCC, L-61.

79 Para Félez Lubelza, a pesar de la tosquedad del cantero que la ejecutó, "las líneas generales de la composición traslucen vivamente el sistema claro y equilibrado de Cano". Félez Lubelza, C., Portadas manieristas y barrocas granadinas, Granada, Caja General de Ahorros, 1992, p. 87.

${ }^{80}$ En un reciente artículo se cuestiona que el dibujo de este retablo sea obra de Alonso Cano y se atribuye al ensamblador Sebastián de Benavente. Aunque los argumentos sean sugerentes, no son determinantes. Las similitudes con la portada de Hospitalicos más bien reforzaría la opinión de que Cano dio traza para el retablo de San Diego. CRUZ YÁBAR, J. M., "Sebastián de Benavente y la capilla de San Diego de Alcalá”, Archivo Español de Arte, 81 (2008), pp. 379-394.

Arch. esp. arte, LXXXIV, 333, ENERO-MARZO 2011, 1-24, ISSN: 0004-0428 
edificio. Una sobria pero articulada moldura enmarca el balcón, destacándola del otro que se abre a pocos metros también en el piso principal. Los muros son sólo de ladrillo en la fachada del templo y en la torre, mientras que en el resto del edificio están fabricados con cajones de mampostería, lo cual podría reforzar la hipótesis de que responden a dos fases constructivas distintas.

El campanario se sitúa en un ángulo oblicuo respecto al templo, alcanzando 23 metros de altura. Una moldura lo divide en dos cuerpos, el primero con tres pisos y el segundo con dos. La ventana del piso bajo es amplia y tiene balaustres de hierro, las del segundo y tercer piso son pequeños óculos enmarcados por molduras de una dimensión similar a la ventana inferior, mientras que el cuarto piso tiene una ventana ciega, rematándose la torre con doble arco de medio punto que aloja la campana ${ }^{81}$. Aunque su sobriedad y el estar realizado en ladrillo nos puedan evocar a los campanarios de las iglesias mudéjares de la ciudad, el vocabulario ornamental es de una interesante abstracción. Las pilastras de los dos cuerpos en lugar de capiteles tienen un sencillo rectángulo y bajo los pequeños óculos hay paneles recortados en forma de T. La propia moldura que divide los dos cuerpos del campanario presenta sencillos rectángulos como sustitución del típico friso de triglifos y metopas ${ }^{82}$.

La fachada a la callejuela Hospital del Corpus Christi cuenta con una sencilla portada de ladrillo con pilastras toscanas, transformada en ventana a finales del siglo XIX para iluminar los pies del templo. Esta portada, así como el campanario, guardan similitudes con la iglesia de la Encarnación de Laujar del Andarax, obra de Juan Luis de Ortega. En la confluencia de esta callejuela con Calderería Vieja está la fachada principal del hospital, con una moldurada puerta de piedra de Elvira que en el dintel ostenta el escudo de la hermandad dentro de un golpe de follaje canesco, sobre él un gran balcón con reja carcelera y como ático unos arcos hoy parcialmente cerrados de una logia o secadero. Esta portada hemos visto que se labró en 1677 para el hospital viejo y, cuando éste fue reconstruido, se colocó de nuevo.

Todo parece indicar que el aspecto exterior del edificio se ha conservado bien, aunque ha sufrido algunas alteraciones que deben citarse. Es muy posible que los paramentos no estuvieran antiguamente en ladrillo visto y hay testimonios, si bien algo confusos, de que el edificio estuvo enlucido con colores tales como el almagra, amarillo y blanco. La portada lateral cegada muestra hoy una afortunada combinación de blanco con los elementos ornamentales en rojo ${ }^{83}$. No muy lejos de este edificio está la iglesia de San Gregorio Bético, que guarda algunas analogías en su torre y cuyo enlucido amarillo y almagra nos puede servir de modelo para imaginar el que pudo tener Hospitalicos ${ }^{84}$. Otra posibilidad es que estuviera decorado con esgrafiados, tal y como puede verse que ocurre todavía en el cuerpo de la cúpula ${ }^{85}$.

La entrada a la iglesia forma un agudo triángulo que sirve para armonizar la calle con la orientación de la nave. El reducido nártex -5 por 3 metros- es ovalado y se cubre con un rosetón canesco en el que confluyen molduras pareadas a modo de nervios. En el lado izquierdo se ubi-

${ }^{81}$ En 1914 se adquiere una campana para la torre más grande que la existente [AHCC, Libro $1 .^{\circ}$ de Consultas (1907-1989), informe del 3 febrero 1914].

82 En 1978 fue preciso reforzar el campanario con viguetas. AHCC, Libro de Cosas Notables (1939-2007).

${ }^{83}$ En 1963 se pintó la fachada del templo en amarillo. En 1978 las fachadas se pintan de blanco, "pues antes lo estaban de amarillo deslucido". AHCC, Libro de Cosas Notables (1939-2007).

${ }^{84}$ Junto a lo que había sido una ermita se establecen los mínimos en 1651 y someten a una profunda remodelación su templo. Sobre la fundación y sucesivas reconstrucciones y reformas de este templo véase De ECHEVERRía, J., Noticias sagradas del glorioso patrono de Granada S. Gregorio el Bético, y de su sacro templo en su fundación, progresos, y presente estado..., Granada, Imprenta de los Herederos de Don Bernardo Turrubia, 1773, pp. 66-138.

85 Por otra parte, los tejados han sufrido importantes reparos en 1909, 1934, 1949 y 1963 . Aunque el aspecto actual parece corresponderse con el original. AHCC, Libro 1. ${ }^{\circ}$ de Consultas (1907-1989) y Libro de Cosas Notables (19392007). 
ca una hornacina con un Ecce Homo y una Dolorosa. Una puerta de piedra gris con el lema de la hermandad, "PAZ. PAZ. PAZ", da acceso a la iglesia. A mediados del siglo XX el "viejo pavimento del atrio" fue reemplazado por el actual a la par que se colocaba un zócalo de mármol casi tan alto como una persona ${ }^{86}$.

La iglesia tiene planta basilical, pero a su vez consta de dos ámbitos perfectamente integrados. Los pies del templo tienen bóvedas bajas de crucería apeadas en columnas toscanas de piedra gris unas y simulándola otras, las cuales soportan el coro y el salón principal de la hermandad. Una gran ventana, situada en el ángulo sur ilumina un espacio del que cabe sospechar que fue la capilla del Santo Christo de la Columna que Juan Luis de Ortega labró antes de que se cerraran las bóvedas del templo ${ }^{87}$. El angosto sotocoro se abre a un diáfano espacio de cruz griega con ligeras bóvedas apeadas sobre cuatro pilares. El contraste entre los dos ámbitos es uno de los principales logros del templo. El cuerpo principal consta de tres naves en planta, pero gracias a las semicúpulas forma una cruz griega, aunque ésta es imperfecta, pues a los pies la nave es más alargada, en la cabecera se prolonga con un ábside y el brazo derecho está ligeramente recortado por la angostura del solar. Sin embargo, todo esto no se percibe a simple vista, y el espacio resulta de una armoniosa unidad. Los sucesivos tramos de la iglesia también varían de tamaño, introduciéndose así un interesante ritmo. En fin, el pequeño templo tiene 25,5 metros de longitud en su nave central, incluida la capilla mayor, y 14 metros en el crucero, sufriendo un ligero estrechamiento de los pies hacia la cabecera.

Como precedente indirecto de la planta puede citarse el proyecto de Bramante para San Pedro del Vaticano, pero su verdadero modelo debió ser la basílica de El Escorial, aunque la diferencia de escalas, materiales constructivos y ornamentación sean tan acusados. Es en El Escorial donde encontramos un sotocoro bajo y oscuro que se abre a una diáfana iglesia que integra la planta basilical y la cruz griega.

La concepción de un espacio cubierto por una cúpula sobre pechinas y cuatro medias cúpulas formando una cruz la encontraremos en edificios posteriores al de Hospitalicos. Podemos citar en Granada el camarín de la Virgen del Rosario, que realiza José de Bada, y el oratorio de los Canónigos de la Catedral, de autor desconocido. En Sevilla destaca la iglesia San Luis de Leonardo de Figueroa (1699-1731) y en el área castellana la iglesia que Manuel y José del Olmo hicieron para las Comendadoras de Santiago en Madrid (1667) o la capilla de San Fausto de la iglesia de Mejorada del Campo (1687-1691), obra de Matías Román. Muchas de estas construcciones son pesadas obras de cantería y no tienen la combinación de la cruz griega con una planta basilical de Hospitalicos. Desde el punto de vista estructural esta iglesia es, además, muy rara en el panorama granadino, ya que se cubre con delgadísimas bóvedas de ladrillo que nos recuerdan más a Santa Sofía de Constantinopla y a San Marcos de Venecia que a los templos barrocos de Andalucía. La cúpula central sobre pechinas y las cuatro bóvedas de cuarto de esfera reposan sobre los pilares, sin apoyar unas en otras. Pero, a diferencia de los edificios bizantinos, hay sobre ellas pesadas armaduras de madera con tejas de arcilla, de ahí también que los muros del templo sean de carga y no ligeros muros cortina.

El principal problema que plantea hoy la iglesia es el de su escasa iluminación, el cual se agrava si consideramos que de las dos ventanas que hay a los pies del templo una es la portada lateral reconvertida en ventana. La mayoría de la luz procede de cuatro pequeñas ventanas que horadan la cúpula y de otras dos más grandes que se abren en las medias cúpulas del crucero, todas de forma ovalada. Los vanos de las medias cúpulas tienen la peculiaridad de abrirse de

\footnotetext{
86 Solería y zócalo se colocaron en 1955. Archivo Histórico Municipal de Granada, legajo 3171 pieza 624.

87 Aunque en principio pudiera sospecharse que la ventana con su reja es moderna, aparece citada con toda claridad en un inventario de 1767. Por otra parte, en la fachada puede observarse que sobre esta ventana hay un pequeño arco de descarga, testigo de un antiguo ventanuco o de una hornacina. ¿Este vano fue puerta antes que ventana?
} 
manera efectista a una triple ventana formada por dos arcos de medio punto separados por una columna y sobre ésta un óculo -solución repetida por Juan Luis de Ortega en la iglesia de la Encarnación de Laujar-. Además, algunas ventanas están hoy veladas y la escasa luz es absorbida por añadidos del siglo XX, como una densa ornamentación pictórica, los zócalos y un abigarrado mobiliario. Por otra parte, la antigua solería de "piedra azul y blanca" fue sustituida en 1913 por loseta hidráulica, excepto la capilla mayor ${ }^{88}$.

La tribuna describe una herradura y cuatro esbeltas columnas toscanas de piedra de Elvira sirven de apoyo a la ligera media naranja. Una barandilla de hierro rematada con esferas de piedra permite una buena visión del altar a los hermanos que se reunían en la inmediata sala del Cabildo. Una tribuna similar a ésta en su atrevida curva es la que años después hizo José de Bada para la iglesia de San Juan de Dios. El actual carácter de coro de la tribuna se lo dieron los agustinos, que a mediados del siglo XX le incorporaron la sala anexa, colocaron una sillería de doce escaños, y una hornacina y un dosel para albergar esculturas ${ }^{89}$.

La ornamentación del templo es uno de sus rasgos más interesantes, aunque esté hoy deslucida por la falta de luz y las pinturas añadidas en $1923^{90}$. Las cuatro pilastras centrales son muy altas, sin mantener proporciones clásicas, y se rematan en una típica combinación canesca de panel recortado y golpe de hojarasca. La cornisa está decorada con una moldura que a intervalos dibuja paneles recortados sobre los cuales hay golpes de hojarasca en forma de ménsulas. En la cúpula los óvalos se ubican entre nervios que parten de adornos vegetales y confluyen en un rosetón. En las medias naranjas las ventanas y las pinturas ovaladas están enmarcadas por carnosos adornos vegetales, que se extienden serpenteando por los plementos y enmarcando tondos de traza geométrica.

En fin, buena parte de la ornamentación tiene su origen en el vocabulario arquitectónico y retablístico de Alonso Cano, en particular los paneles recortados y los caprichos vegetales que adornan pilastras y cornisas, quizás diseñados por Juan Luis de Ortega. Pero las ventanas y las medias naranjas presentan también sinuosos y abigarrados despliegues vegetales ajenos a su estilo, y que responden a un barroco más tardío. Por otra parte, la ornamentación de la media cúpula del ábside de la capilla mayor es distinta, pues evoca a una venera. Es evidente que los puntuales ornamentos que pudieran colocarse al cerrar la cúpula en 1668 debieron parecer demasiado austeros en 1690 y se pidió al artífice José Sánchez que los enriqueciera, extendiendo su labor a otros puntos del edificio.

El templo tuvo una sacristía "muy incapaz e indecente"91 antes de que se habilitara la que hoy podemos ver, que posiblemente fue antes una sala del hospital. La sacristía se encuentra tras el altar mayor y se accedía a ella por una puerta situada en la nave derecha, hasta que los jesuitas, usuarios de la iglesia a finales del siglo XIX, abrieron una puerta en el centro del ábside. La sala se encuentra sensiblemente inclinada respecto al eje del templo y sin formar un perfecto rectángulo, porque ha de adaptarse a la forma irregular del solar. En 1925 la sacristía fue ampliada al tabicar la antigua puerta del Hospital y suprimir el vestíbulo y la escalera a las que daba acceso ${ }^{92}$.

88 AHCC, Libro 1. ${ }^{\circ}$ de Consultas (1907-1989), 16 de junio de 1913.

89 AHCC, Libro de Cosas Notables (1939-2007), marzo de 1956.

90 Entre 1923 y 1924 toda la iglesia fue pintada por Luis Palomares, autor de los cinco medallones pintados al fresco con escenas de la vida de San Agustín y de mártires agustinos. "Los PP. Agustinos Recoletos en Granada. El 25. Aniversario de la fundación de la Residencia", Boletín Oficial de la Provincia de Santo Tomás de Villanueva, $1924-1925$

${ }^{91}$ Queja presentada en la reunión de la hermandad del 21 de diciembre de 1719 (AHCC, L-52). Otra queja, de carácter distinto, se escucha en una reunión del 31 de diciembre de 1745 porque la sacristía carecía de "ornamentos con los que decir misa" (AHCC, L-61). En el inventario de 1767 la sacristía ya debe de ser la actual (AHCC, L-42).

92 También en 1925 se enriquece la sacristía con nuevos armarios y cajonería [AHCC, Libro $1 .^{\circ}$ de Consultas (1907-1989), 11 de junio de 1924 y BOPSTVA, abril de 1925]. En 1957 los hermanos Romero hacen para la sacristía el armario central. Y en 1975 volvió a remozarse la sacristía (AHCC, Libro de Cosas Notables, 1939-2007). 
Bajo el ábside del altar mayor y la sacristía hay una espaciosa cripta con bóvedas de crucería y cañón, en la que destaca una robusta columna toscana. En este lugar se enterraban los miembros de la hermandad y sus familiares.

A partir de un inventario de 1807 podemos deducir las dependencias con que contaba el hospital. Se accedía por un portal desde la calle Calderería Vieja, el cual daba acceso a un cuarto con la tinaja de agua ${ }^{93}$. Del portal arrancaba la escalera principal, que nos llevaba a diversas habitaciones, entre ellas la enfermería, una alcoba y la cocina con su granero. Desde una de las salas había una ventana que permitía a los enfermos escuchar misa sin bajar al templo. Todas estas dependencias, situadas tras la cabecera del templo, están hoy muy reconstruidas y el único elemento de interés subsistente, que se encuentra en la actual sala del archivo, es un nicho con yeserías de paneles recortados y hojarascas.

En el extremo opuesto, o sea, sobre el nártex y el primer tramo de la iglesia, se encuentran varias habitaciones que tuvieron diversos usos, sobre todo los de sala del Cabildo y vivienda rectoral. De estas salas destacan en particular dos por sus originales bóvedas con golpes de hojarasca talladas por José Sánchez.

Todas estas dependencias rodean en buena parte al templo y le dan al inmueble un aspecto compacto y civil, sólo alterado por el campanario. Los tejados de la iglesia quedan ocultos para el viandante, con lo cual se evita ver coronado el edificio con unos volúmenes confusos consecuencia de la disposición oblicua de aquélla.

\section{Conclusiones}

Gracias al extraordinario fondo documental que posee el Hospital del Corpus Christi es posible establecer en este artículo un proceso constructivo y delimitar unas autorías más allá de lo que las fuentes documentales suelen permitir en esta época para la mayoría de los edificios. Obtenemos así un conocimiento bastante completo de un inmueble que se construye en un época crucial, la del pleno barroco, y que, sin tener ningún eco manierista, abre caminos que la arquitectura barroca granadina y andaluza continuará desarrollando.

El proceso constructivo podría resumirse así: Por encargo del escultor y mayordomo de la hermandad Pedro de Mena, en 1654 se pone la primera piedra del templo y se colocan los cimientos, todo siguiendo un proyecto de Bernabé Martín que es aprobado en una reunión por Alonso Cano, José de Rueda y otros artífices. Por falta de presupuesto la obra quedará paralizada durante varios años, hasta que bajo la dirección de Juan Luis de Ortega se da un fuerte impulso que culmina en 1668, un año después de su muerte, con el cierre de la cúpula. El viejo templo y el hospital siguen funcionando, pero hacia 1678 se abre la nueva iglesia, a la que se trasladan las pinturas, esculturas y demás enseres de la antigua. Quedan aún muchas tareas pendientes, las cuales se abordarán entre 1685 y 1692, a saber, la construcción de la torre, la ejecución de la portada del templo, la colocación de tejados, la labra de las yeserías y la construcción del hospital nuevo tras derribar el antiguo. En esta fase de las obras destacan como artífices el tallador de yesos José Sánchez y el cantero Francisco de Cárdenas.

Sin embargo, algunas preguntas y dudas se han resistido a la exploración documental y bibliográfica. La original traza de Bernabé Martín, sin precedentes en el panorama andaluz, parece ser la de alguien con amplios conocimientos de arquitectura desarrollados más allá de las propias fronteras regionales. Después de que diera las trazas, su nombre no vuelve a relacionarse con el edificio, mientras que son muchos los artífices que a lo largo de los años vemos vinculados a la

93 En ese lugar hubo un pilar que fue retirado en 1802 por las filtraciones que provocaba. AHCC, L-85. 
construcción. Si la mayoría son personas que hemos de pensar sólo se limitaron a ejecutar lo trazado, otros son maestros de indudable peso que sin lugar a dudas dejaron una huella, en particular Juan Luis de Ortega, el discípulo más directo que en el campo de la arquitectura tuvo Alonso Cano, y el tallador de yeso José Sánchez, destacada figura en la transición del pleno barroco canesco al tardío barroco. En fin, no me cabe la menor duda de que la ornamentación nada debe a Bernabé Martín y sí mucho a Juan Luis de Ortega y a José Sánchez. La aportación de este último es clara, pero la del primero no tanto debido a lo lacónicas que se muestran las fuentes documentales; para delimitar su posible aportación sería útil retirar los repintes y realizar análisis químicos de la composición del yeso, prestando especial atención a los adornos que hay en las bóvedas de los pies del templo y en las pilastras de la cúpula, que pueden ser los que tengan una cronología diferente al resto de la profusa ornamentación. Por otra parte, la original portada del templo, aunque deslucida por una tosca ejecución, es obra indudable de Alonso Cano, quien es probable que por petición de Pedro de Mena o de Juan Luis de Ortega hiciera otras aportaciones.

Fecha de recepción: 14-VII-2009

Fecha de aceptación: 15-XI-2009 